Ankara Üniversitesi Eğitim Bilimleri Fakültesi Dergisi

Yll: 2020, Cilt: 53, Sayl: 2, 515-548

DOI: 10.30964/auebfd.683744, E-ISSN: 2458-8342, P-ISSN: 1301-3718

Video-Duruma Dayalı Öğretimde Bir Yöntem:

Öğretmen Adaylarının Kendi Deneyimlerinin

Kurgulanması ve Tartışılması ${ }^{1}$

\begin{tabular}{lccc}
\hline MAKALE TÜRÜ & $\begin{array}{c}\text { Başvuru Tarihi } \\
\text { Araştırma Makalesi }\end{array}$ & $\begin{array}{c}\text { Kabul Tarihi } \\
09.05 .2020\end{array}$ & $\begin{array}{c}\text { Yayın Tarihi } \\
09.05 .2020\end{array}$ \\
\hline \multicolumn{4}{c}{ Raziye Sancar (D) 2} \\
Kırşehir Ahi Evran Üniversitesi \\
Deniz Deryakulu (iD) 3 \\
Ankara Üniversitesi
\end{tabular}

Öz

$\mathrm{Bu}$ araştırmada, öğretmen adaylarının kendi sınıf-içi öğretim deneyimleriyle kurguladıkları video-durumların akranları ile yüzyüze tartışılmasını içeren video-duruma dayalı öğretim sürecinin ayrıntılı olarak incelenmesi amaçlanmıştır. $\mathrm{Bu}$ amaçla araştırma, nitel araştırma yaklaşımı benimsenerek durum çalışması (case study) olarak yürütülmüştür. Araştırmanın çalışma grubunda, 2016-2017 öğretim yılında Ankara Üniversitesi Eğitim Bilimleri Fakültesi BÖTE Bölümünde Öğretmenlik Uygulaması dersini ilk kez alan ve derse devam eden 16 (9 kadın, 7 erkek) öğretmen adayı yer almaktadır. Araştırma süreci, öğretmen adaylarının sınıf-içi öğretim deneyimlerinin kaydedilmesini ve deneyimlerin öğretmen adayları tarafindan kurgulanmasını, kurgulanmış video-durumların yüzyüze ortamda tartışılmasını içermektedir. Araştırmanın verileri süreç sonunda öğretmen adaylarıyla yarı yapılandırılmış görüşme formu kullanılarak yapılan süreç değerlendirme görüşmelerinden elde edilmiştir. Araştırmada videoduruma dayalı öğretim sürecinde, öğretmen adaylarının kendilerini izleme olanağı bulmalarının, hem kendilerinde hem de arkadaşlarındaki değişimi fark etmelerinin, eleştirme ve eleştirilme konusunda gelişim göstermelerinin, akranları tarafindan beğenilmelerinin ve süreçte düşüncelerinin önemsenmesinin değerli ve önemli görüldüğü belirlenmiştir. Ayrıca sürecin, öğretmen adaylarına deneyim biriktirme, tartışabilme ve eleştiri kabul edebilmenin yanı sıra, okul rehber öğretmenlerinden alınamayan geribildirimleri edinebilme konularında yarar sağladığı saptanmıştır. Süreçte katılımcıların sayıca yoğunluğu, deneyimlerin çeşitliliğine katk1 sağlarken özellikle zaman açısından uygulama sürecinin maliyetini arttırmaktadır. Bu durumun en uygun biçimde düzenlenmesinin ya da tartışma oturumlarının sınırlarının sürecin başlangıcında ayrıntılı belirlenmesinin, uygulama sürecini görece daha uygulanabilir kılacağı ve süreçten elde edilecek yarara katkı sağlayacağı düşünülmektedir.

Anahtar sözcükler: Video-durum, video duruma-dayalı öğretim, video kurgulama, videotartışma, öğretmen eğitimi.

${ }^{1} \mathrm{Bu}$ araştırma, Raziye Sancar'ın ikinci yazar yönetiminde hazırladığı “Öğretmen Adaylarının Kendi VideoDurumlarının Öğretimsel Kararlarının Çözümlenmesinde Kullanımı Üzzerine Nitel Bir Araştırma” adlı doktora tezinden üretilmiștir.

${ }^{2}$ Sorumlu Yazar: Dr., Kırşehir Ahi Evran Üniversitesi, Eğitim Fakültesi, BÖTE Bölümü, E-posta: raziyesancar@gmail.com, https://orcid.org/0000-0002-2875-9233

${ }^{3}$ Prof. Dr., Ankara Üniversitesi, Eğitim Bilimleri Fakültesi, BÖTE Bölümü, E-posta: deryakulu@ankara.edu.tr, https://orcid.org/0000-0002-6974-7183 
Sınıflar sosyal olarak yapılandırılmış karmaşık bir yapıya sahiptir. Durumsal değişkenler ve öğretim bağlamı öğretme işini doğrudan etkilemektedir (Payne, Bettman, Johnson, 1988; Duffy, Miller, Parsons ve Meloth, 2009; Frost, 2010; Johnson ve Matthews, 2017; Kennedy, 2019). Bir süreç olarak öğretim, durağan olmamakla birlikte sürekli değişimler, görüşmeler, eylemler ve sayısız değişkenlere verilen yanıtları/tepkileri içermektedir. Dolayısıyla öğretme işi, öğretmen adaylarına bir sınıftaki karmaşık durumların tamamına aynı anda yollamada (atıfta) bulunan, mikro (küçük/dar) ve makro (büyük/geniş) düzeydeki yapılar arasında gerçekleşen etkileşimleri içerisinde barındıran bir süreç olarak aktarılmanın (Schieble, Vetter ve Meacham, 2015) yanı sıra, öğretmen adayları tarafindan yapılandırılmayı da gerektirmektedir (Averill, Drake, Anderson ve Anthony, 2016; Eilam ve Poyas, 2009). Buna karşın ülkemizde, öğretmen eğitimi programlarının genellikle içerik bilgilerinin aktarılması ağırlıklı tasarlandığı görülmektedir. Öğretmen adaylarının uzmanlaşma yönünde ilerleyebilmeleri için gerekli olan gerçek sınıf-içi öğretim durumlarına ilişkin farkındalıklarını ve öğretim deneyimlerini geliştirmeye odaklanan bir öğretmen yetiştirme sürecinin varlığından söz etmek pek de olanaklı değildir. Öğretmen yetiştirme programlarıyla ilgili araştırmalar, içeriğe ilişkin kuramsal bilgilerin uygulama süreçleri ile bütünleşik olmamasının pek çok sorunu beraberinde getirdiğine işaret etmektedir (Hiebert, Morris, Berk ve Jansen, 2007; Jiang, Ganoe ve Carroll, 2010; Korthagen, 2010; Merseth; 1994; Shulman, 1992). Mesleğe yeni atılan öğretmenler genellikle aldıkları kuramsal derslerde öğrendiklerini, sınıf-içi öğretim uygulamalarına aktaramamaktadırlar. Başka bir söyleyişle öğretmen adayları, öğretmen eğitimi sürecinin ardından mesleğe geçiş sürecinde, sıklıkla okul ortamı ile öğretme ve öğrenmenin gerçekleri arasında kopukluklar yaşamaktadırlar (Nielsen, 2015; Schieble ve diğ., 2015). Öğretmen adaylarının süreçte, özellikle öğrencilerin içeriğe ilişkin düşüncelerini fark etme ve sınıf-içi öğretim deneyimlerini bu doğrultuda düzenleyebilecek kararlar alma konusunda yaşadıkları sorunların (Sherin ve Van Es, 2005; Stockero, Rupnow ve Pascoe, 2017; Sun ve van Es, 2015), temelde öğretimin durumlu ve bağlama özgü niteliği göz ardı edilerek tasarlanan öğretmen eğitimi süreçlerinden kaynaklandığı belirtilmektedir (Kennedy, 2019). Ayrıca öğretmen eğitimi sürecinde öğretimin bağlama özgü niteliğinin göz ardı edilmesi, öğretmen eğitimi programları ve ders içeriklerinin uygulamaya aktarılması zor, ideal ya da gerçekçi olmayan biçiminde değerlendirilmesine yol açmaktadır (Schieble ve diğ., 2015). Bu durum, öğretmen adaylarının kuramsal bilgi ve gerçek öğretim uygulamaları hakkında iki ayrı dünya algısı oluşturmalarına neden olmaktadır (Nielsen, 2015).

Ülkemizde meslek öncesinde ve meslek yaşamlarında bilişim teknolojisi öğretmenlerinin yaşadıkları sorunların temelinde öğretmen eğitimi programlarının gerçek yaşam durumları için yetersizliği (Deryakulu ve Olkun, 2007), dolayısı ile uzmanlık geliştirmeyi desteklememesi yer alırken bunun yanı sıra öğretmen eğitimi programlarının özellikle kuramsal bilgiden/içerik bilgisinden çok uygulama bilgisi gereksinimini karşılamakta yetersiz kaldığı da belirtilmektedir (Duman, 2012; Topuz, 2010). Eğitimleri süresince alan deneyimi sağlamak amacı ile öğretmen adaylarına 
tanınan olanakların onlara okula uyum sağlama, okul ortamını tanıma, yeterince örnek görme ve yeterli sayıda ders anlatma firsatı yaratma konusunda da zayıf kaldığı belirtilmektedir (Arkün-Kocadere ve Aşkar, 2013; Ekiz, 2006). Söz konusu bu firsat eksikliği, öğretmen adaylarının sınıf-içi öğretim deneyimleri sırasında özellikle öğretimin planlanması (Çakır ve Yıldırım, 2006), sınıf yönetimi (Arıcı, 2007), zaman yönetimi ve öğretim becerisi ile doğrudan ilişkili öğretimsel kararlar alma süreçlerinde zorlanmalarına neden olmaktadır (Ekiz, 2006). Öğretmen adaylarına yalnızca bilgi ve içerik aktarımı yerine, onların sınıf içerisindeki karmaşık durumları deneyimleyebilecekleri probleme-dayalı öğretim, duruma-dayalı öğretim ve bilişsel çıraklık gibi pek çok öğretim yönteminden yararlanmak olanaklıdır.

Öğretmen eğitiminde video-duruma dayalı öğretim yönteminin kullanımına ilişkin pek çok araştırma bulunmakta ve bu araştırmalarda durumların (cases) öğretmen yetiştirmede sağladığ 1 yararlara sıklıkla değinilmektedir (Høynes, Klemp, ve Nilssen, 2019; Koç, Peker ve Osmanoğlu, 2009; Lee ve Wu, 2006; Maclean ve White, 2007; Moreno ve Ortegano-Layne, 2008; Perry ve Talley, 2001; Rich ve Hannafin, 2009; Wright, 1996; Yerrick, Ross ve Molebash, 2005; Yung, Wong, Cheng, Hui ve Hodson, 2007). Öğretmen eğitiminde video-durumlar; kuramsal yapının ilke ve kavramlarını, uygulama için birincil öncelikli bilgileri, etiği ve ahlakı, yöntem ve tekniği, istek ve düşünce alışkanlıklarını ya da olası durumlar için bakış açısı geliştirmeyi sağlamak gibi pek çok amaca yönelik olarak kullanılabilmektedir (Shulman, 1992). Bunun yanı sıra video-durumlar, öğretmen adaylarına gerçek sınıf ortamlarını keşfetme, çözümleme ve bu ortamlar üzerine düşünme olanağı tanımaktadır (Merseth, 1994). Başka bir söyleyişle video-durumlar, öğretmen adaylarına, gerçek yaşam sorunları hakkında nasıl ustaca düşünülebileceğine ilişkin örnek sağladığından, video-duruma dayalı öğretim süreci, sınıf-içi etkinliklerin karmaşıklığını öğretimin merkezine alarak öğretmen adaylarının kuramsal bilgileri, kavramları ve gerçek yaşamı birleştirmelerine olanak sağlayabilmektedir (Kurz, Llama ve Savenye, 2004). Ayrıca video-durumlar, öğrenmeye yönelik güdülenme sağlamakta, hem ön öğrenmelerde hem de ilkelerin öğrenilmesinde oluşabilecek tehlikeli genellemelere çözümler/seçenekler üretmeyi desteklemekte ve tartışma ile değerlendirmelere olanak tanımakta olup (Shulman, 1992) öğretmen adaylarının kendi deneyimleri ya da diğerlerinin deneyimlerinden öğrenmelerini de sağlamaktadır (Merseth,1996).

Duruma-dayalı öğretim yönteminde, süreçte kullanılması planlanan videodurumların içeriği, öğretim sürecinin amacı ile koşut biçimde düzenlenmektedir. Video-durumların içeriği öğretmen adaylarının kendi sınıf-içi öğretim deneyimlerinden ya da deneyimli ya da deneyimsiz başka öğretmenlerin (diğerlerinin) öğretim deneyimlerinden oluşturulabilmektedir. Her ne kadar video-durum üretimine ilişkin maliyetli süreçler ve süreçte yer alacak öğretmen adaylarının sayısı gibi durumlar diğerlerinin video-durumlarının kullanımını yaygınlaştırsa da uygun koşullar sağlandığında, öğretmen adaylarının kendi sınıf-içi öğretim deneyimlerini içeren video-durumlar süreçten elde edilecek yarara ayrıca katkı sağlamaktadır (Civitillo, Juang, Badra ve Schachner, 2019). Öğretmen adaylarının kendi sınıf-içi 
öğretim deneyimlerini kendilerinin kurgulamaların gerektiren öğretim süreçleri, deneyimlerini ayrıntılı biçimde izlemelerine, daha bütüncül değerlendirmelerine olanak tanımakta ve video-durum geliştirme süreci öğretmen adaylarının mesleki gelişimlerini desteklemektedir (Jensen, Shepston, Connor ve Killmer, 1994). Ayrıca video-durum kurgulama süreçleri, kendi sınıf-içi öğretim deneyimleri üzerinden öğretmen adaylarının öğrenci gibi düşünme ve öğrencilerin isteklerini anlayabilmelerine (Koç, 2011), öğretmen-öğrenci arasındaki iletişim ve etkileşime odaklanabilmelerine (Rosaen ve diğ., 2009) ve sürece ilişkin farkındalık geliştirebilmelerine de olanak tanımaktadır (Baecher, Kung, Jewkes ve Rosalia, 2013).

Duruma-dayalı öğretim sürecinde öğretmen adaylarının çözümleme, bakış açısı geliştirme ve yansıtıcı düşünme becerilerinin geliştirilebilmesi için durum tartışmalarının rolü oldukça önemlidir (Merseth, 1996). Duruma-dayalı öğretim yöntemi ile durumların tartışılması süreçte iki temel bileşen olarak yer almaktadır. Durumlar olmadan yalnızca tartışma yöntemi ile içerik, yüzeysel ve eksik kalırken yalnızca durumların aktarılması ile de öğretilmek istenilen ile öğrenilen arasındaki farkın bilinmesi olanaklı değildir (Merseth, 1991). Durumların tartışılması aracıllı̆̆ ile öğretmen adaylarında anlamlı ve derin öğrenmeyi sağlamak, yansıtıcı düşünmeyi geliştirmek ve öğretmen adaylarının mesleki gelişimlerini desteklemek olanaklıdır (Schieble ve diğ., 2015; Sherin, 2007). Ayrıca durumların tartışılması ve değerlendirilmesi ile öğretmen adaylarına hem uzmanlar hem de akranları tarafindan, sınıf-içi öğretim deneyimleri sırasında gereksinim duydukları dönütler sağlanabilmektedir (Miyata, 2002).

Öğretmen eğitiminde mesleki bilgi, inançlar ve öğretim deneyimleri arasında önemli bir arabulucu olarak duruma özgü beceriler, günümüzde giderek daha fazla dikkat çekmektedir (Meschede, Fiebranz, Möller ve Steffensky, 2017). Bağlama özgü becerilerin aktarılmasında video-duruma dayalı öğretim, önemli bir yöntem olarak görülmekte olup video-durumlar öğretmen adaylarının farklı bağlam ve durumlara erişimlerinin yanı sıra diğerlerinin uygulama deneyimlerinden yararlanılmasını da sağlamaktadır (Olkun, Altun ve Deryakulu, 2009). Video-duruma dayalı öğretim yöntemi ile öğretmen adaylarının sınıf-içi öğretim deneyimlerine ilişkin fark etme becerilerini geliştirmek olanaklıdır (Brunvand, 2010; Johnson ve diğ., 2019; Page ve Jones, 2018; Stockero ve diğ., 2017). Ayrıca duruma-dayalı öğretim yöntemi ile öğretmen adaylarına süreçte akranları ve danışmanları ile düzenli olarak tartışma olanağı tanınması ve tartışmalarda öğretmen adaylarının kendi uygulama deneyimlerinin kullanılması, öğretmen eğitimi için oldukça önemli bir adım olarak görülmektedir (Moore, 1998). Video-duruma dayalı öğretim yöntemi kullanılarak öğretmen adaylarına duruma özgü becerileri aktarmak, birden fazla deneyim sunmak, düzenli dönütler vermek ile öz ve akran değerlendirmesi sağlamak olanaklıdır. Dahası, video-duruma dayalı öğretim yöntemi ile öğretmen adaylarında deneyimler üzerine yansıtıcı düşünme becerisi geliştirmesi ve kuramsal bilginin uygulamada kullanılması desteklenebilmektedir. Buna koşut olarak araştırmada, öğretmen adaylarının kendi deneyimlerinin kurgulanması ve tartışılması biçiminde tasarlanan 
video-duruma dayalı öğretim sürecinin, süreçte etkin rol alan öğretmen adayları tarafından değerlendirilmesi amaçlanmaktadır.

\section{Yöntem}

$\mathrm{Bu}$ bölüm araştırma modeli, sınıf-içi öğretim deneyimlerinin kurgulanması, çalışma grubu, verilerin toplanması ve çözümlenmesi ile kodlama ve çözümleme örneği başlıkları altında ayrıntılandırılmıştır.

\section{Araştırma Modeli}

Öğretmen adaylarının ilk öğretmenlik deneyimlerinin video biçiminde kaydedilmesi ile yapılandırılmaya başlanan, bu deneyimlerin kendileri tarafindan kurgulanması, akranları ile kurgulanan deneyimler üzerinden tartışılması biçiminde geliştirilen video-duruma dayalı öğretim sürecinin incelenmesini amaçlayan bu çalışma; nitel araştırma yaklaşımı benimsenerek durum çalışması (case study) olarak yapılandırılmıştır. Durum çalışması, sınırları belirlenmiş bir sistemin kapsamlı olarak tanımlanması ve çözümlenmesi; olayın, programın, etkinliğin, sürecin ve hatta bir ya da birden fazla bireyi sorgulama stratejisi olarak tanımlanmaktadır (Merriam, 2009). Durum, tek bir kişi, birden fazla birey (birlikte ya da bireysel), bir program, bir olay ya da etkinlik olabilirken aynı zamanda bir dizi etkinlikten oluşan çeşitli aşamalar içeren bir süreci de yansitabilmektedir (Creswell, 2011). Bu araştırmada durum, araştırma sürecinin kendisi olup birden fazla etkinliğin yer aldığı ve çeşitli aşamaların bir arada tasarlandığı bir süreçtir. Araştırmanın durumuna ilişkin ayrıntılı ve aşamalı bilgi Şekil 1'de yer almaktadır.

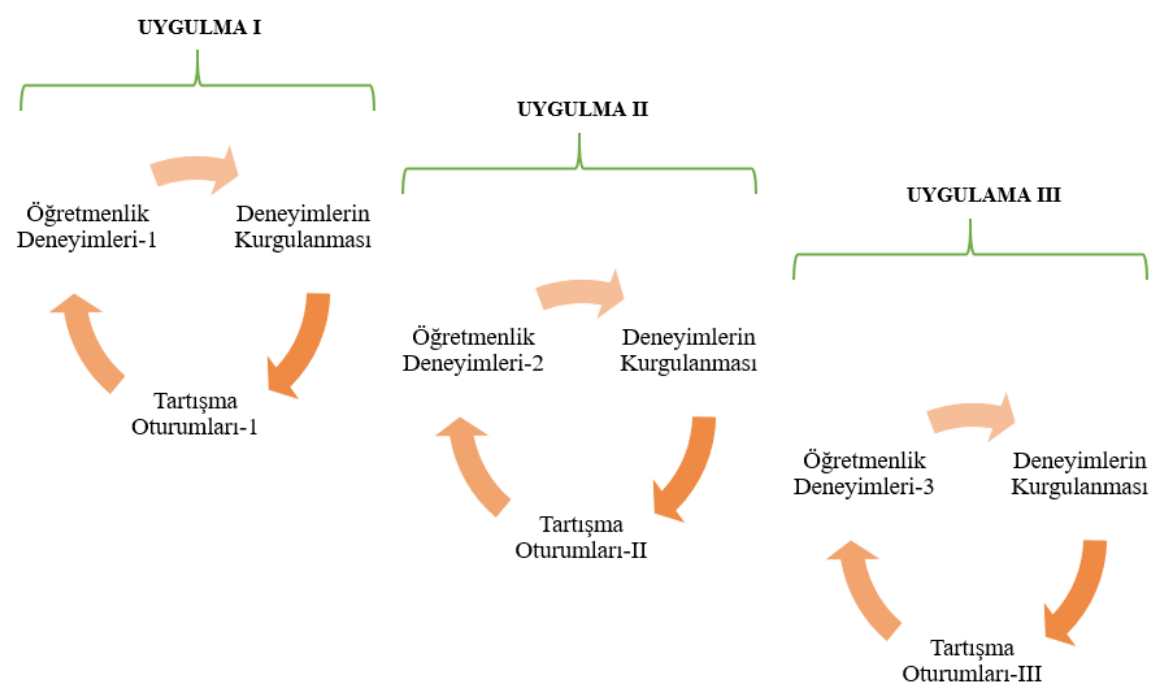

Şekil 1. Video-duruma dayalı geliştirilen öğretim süreci 
Öğretmen adaylarının süreçten haberdar edilmesi ve teknik bilgilendirmelerin yapıldığı seminer süreci ile başlayan, öğretmenlik deneyimlerinin kaydedilmesini, bu video kayıtların öğretmen adayları tarafından kurgulanmasını, kurgulanmış videodurumların tartışma oturumlarında tartışılmasını içeren öğretim süreci durum olarak incelenmiştir. Her bir aşama tüm öğretmen adayları için üçer ayrı öğretmenlik deneyimi için tekrarlanmıştır. Başka bir söyleyişle öğretmen adaylarının ardışık olarak (süreçte uygulama döngüsünün tamamlanmasının ardından) üç farklı sınıf-içi öğretim deneyimleri kaydedilmiş, kendileri tarafından kurgulanmış ve akranları ile tartışılmıştır. Çalışma grubunda yer alan öğretmen adaylarının her biri süreç sonunda üç kurgulanmış video-durum materyali geliştirmiş olup her bir aşamada 16 olmak üzere toplamda 48 farklı sınıf-içi öğretim deneyimi izleme ve tartışma olanağı bulmuşlardır.

\section{Sınıf-içi Öğretim Deneyimlerinin Kurgulanması}

Öğretmen adayları süreçte, kaydedilen sınıf-içi öğretim deneyimlerinden videodurum materyali oluşturmuşlardır. Video-durumlarda öğretmen adayları, deneyimleri sırasında gerçekleşen olayları ve bu olaylara ilişkin iyi olduğu düşünülen durumları (IOD) ve daha iyi olabileceği düşünülen durumları (DİOD) bir araya getirip kurgulayarak video-durumları oluşturmuşlardır (Şekil 2).

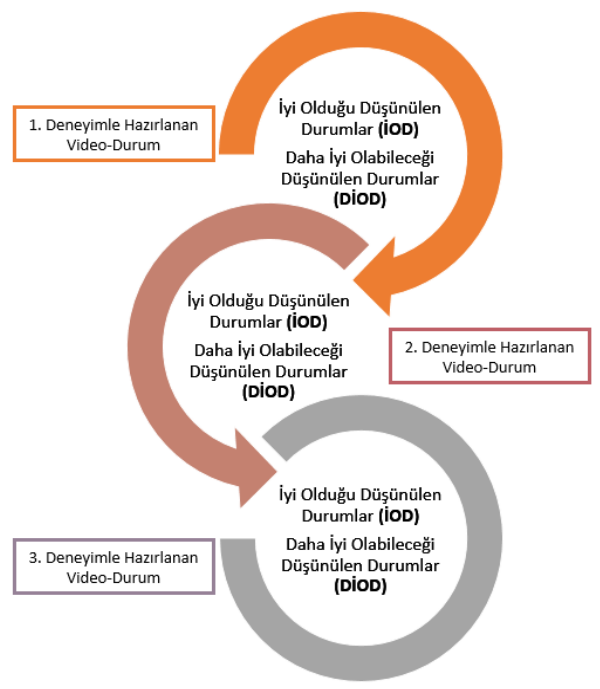

Şekil 2. Deneyimlerden video-durum oluşturulması süreci

\section{Çalışma Grubu}

Araştırmanın çalışma grubu belirlenirken maksimum çeşitliliğin sağlanması amacıyla araştırma sürecinin yapılandırıldığı dönemde gidilebilecek uygulama okulları dikkate alınmıştır. Çalışma grubunda yer alacak öğretmen adaylarının bu 
okullara göre sayıca dağılımlarına özen gösterilmiştir. Başka bir söyleyişle her uygulama okulundan en az bir öğretmen adayının çalışma grubunda yer almasına dikkat edilmiştir. Çalışma grubuna ilişkin bilgiler Tablo 1'de yer almaktadır.

Tablo 1

Çalışma Grubunun Uygulama Okullarına Göre Dağılımı

\begin{tabular}{ccc}
\hline Uygulama Okulu & Öğretmen Adayı \\
\hline O1 & $\mathrm{K} 1$ \\
O2 & $\mathrm{K} 3, \mathrm{~K} 6$ \\
O3 & $\mathrm{K} 2, \mathrm{~K} 5, \mathrm{E} 2$ \\
$\mathrm{O} 4$ & $\mathrm{~K} 9, \mathrm{E} 3$ \\
& O5 & $\mathrm{E} 6, \mathrm{E} 7, \mathrm{~K} 7, \mathrm{E} 5$ \\
& O6 & $\mathrm{K} 4, \mathrm{~K} 8, \mathrm{E} 1, \mathrm{E} 4$ \\
\hline Toplam & $\mathbf{6}$ & $\mathbf{1 6}$ \\
\hline
\end{tabular}

Tablo 1'de görüldüğü üzere, araştırmanın çalışma grubunu 2016-2017 öğretim yılında Ankara Üniversitesi Eğitim Bilimleri Fakültesi BÖTE Bölümünde Öğretmenlik Uygulaması dersini ilk kez alan ve derse devam eden 16 (9 kadın, 7 erkek) öğretmen adayı oluşturmaktadır.

\section{Verilerin Toplanması ve Çözümlenmesi}

Diğer araştırma yöntemlerinin aksine, durum çalışmalarında veri toplama aracı ya da verilerin çözümlenmesi için herhangi bir özel teknik bulunmamaktadır. Verilerin toplanması sürecinde durum çalışmalarında gözlemler, görüşmeler, belgeler ve görsel-işitsel materyaller gibi birçok bilgi kaynağından yararlanılmaktadır (Creswell, 2007). Araştırmada temel veri kaynağı olarak görüşmeden yararlanılmış olup katılımcılar ile uygulama süreci sonrasında görüşülmüştür. Araştırmada görüşme öncesinde ilgili alanyazın okunarak görüşme sorularının yer aldığı yarı yapılandırılmış görüşme formu hazırlanmıştır. Söz konusu görüşme formuna son biçimi verilmeden önce alan uzmanı dört akademisyenden görüş alınmıştır. Alan uzmanlarının geribildirimlerine göre görüşme formunda gerekli düzenlemeler yapılmıştır.

Durum çalışmalarında verilerin metinlere aktarılmasının ardından, çözümleme işlemi için pek çok yöntem bulunmaktadır. Bütüncül çözümleme, hiyerarşik (sıradizinsel) çözümleme ve tarihsel çözümleme bu yöntemler arasında yer almaktadır (Creswell, 2007). Verilerin çözümlenmesinde izlenen süreçte tümevarımcı yaklaşım benimsenmiş olup (Patton, çev. 2014) verilerin kodlanması, kodların anlamsal bütünlük oluşturacak biçimde bir araya getirilmesi ile kategorilerin oluşturulması ve son olarak kategoriler daha geniş anlamlar oluşturacak biçimde bir araya getirilerek ana temalar oluşturulması aşamaları sırasıyla izlenmiştir. Araştırmanın veri birimi, katılımcının bir duygu ya da olguyu tanımlamak için kullandığ 1 bir sözcük kadar küçük ya da belirli bir olayı açıklayan birkaç sayfa metin kadar büyük olabilir 
(Merriam, 2009). Dolayısıyla bu araştırmada süreç değerlendirme görüşmeleri çözümlenirken kodlama birimi cümle olarak belirlenmiştir.

Kodlama ve çözümleme örneği. “Az önce söylediklerimin dışında öğretmenlik uygulaması anlamında çok şey kattı yani biraz daha alıştım, sınıfa alıştım, sürece alışım." (E1) Söz konusu bu ifade öncelikle "öğretmenlik uygulaması süreci ve ders sürecine alışma" olarak kodlanmıştır.

"Bir bakıyorum yalnızca tek taraflı ilgilenmişim, bir bakıyorum parmakları görmemişim, bir bakıyorum kendi kendime konuşuyorum falan.” (K6) biçimindeki bu ifade öncelikle "sınıf yönetebilme becerisi geliştirme" olarak kodlanmıştır.

"Fazlasıyla en basitinden, ilk videoda yaptığım hataları yapmadım mesela, en basitinden ellerim sürekli şöyleydi, ikinci videoda bunu yapmadım mesela." (E6) ifadeleri öncelikle "deneyim iyileştirme" olarak kodlanmıştır.

Öğretmenlik uygulaması süreci ve ders sürecine alışma, sınıf yönetebilme becerisi geliştirme, deneyim iyileştirme ve diğer kodlar birlikte öğretmen adaylarının sınıf-içi öğretim deneyimlerini izlemeleri ile ilgili olarak; "deneyimlerinden öğrenebilme" kategorisi altında toplanmıştır. Her bir kategori için benzer sürecin uygulanmasının ardından öğretmen adaylarının kendi deneyimlerini izlemelerinin; her öğretmenin ve öğretmen adayının yaşaması gereken, farklı ve keyif veren, sınıf içerisinde gerçekleșenlere yönelik farkındalık geliștirebilmeye, deneyimleri değerlendirebilmeye ve deneyimlerinden öğrenebilmeye olanak tanıyan bir deneyim olduğunu açıkladıkları belirlenmiştir.

\section{Geçerlik ve Güvenirlik}

Nitel araştırma yaklaşımı benimsenerek tasarlanan araştırmalarda araştırmanın doğası gereği güvenirlik kavramı, sonuçların toplanan verilerle tutarlı olup olmadığ 1 ile ele alınmaktadır. Nitel araştırmalarda ilk olarak Lincoln ve Guba (1985) tarafindan güvenirliği ifade etmek için kullanılan tutarlılık (akt., Merriam, 2009), araştırma tekrar edildiğinde benzer bulgulara ulaşılmasından çok, sonuçların toplanan verilerle tutarlı olup olmadığı ile ilgili bir kavramdır. Araştırmada Lincoln ve Guba (2013) tarafından önerildiği üzere, sürecin tasarlanmasından, görüşme sorularının hazırlanmasına, verilerin çözümlenmesine ve yorumlanmasına kadar sürecinin her aşaması, biri yöntem bilim uzmanı, üçü konu alanı uzmanı olmak üzere dört uzman tarafından denetlenmiş̧ir. Araştırma sürecinin alan uzmanlarınca denetlenmesi ile araştırmanın tutarlığını; araştırmanın bulgularına ve yorumlarına ilişkin uzman geribildirimleriyle araştırmanın onaylanabilirliğini arttırmak amaçlanmıştır. Nitel araştırmalarda geçerlik kavramı inanırlık ve aktarılabilirlik kavramlarıyla ele alınmaktadır (Merriam, 2009). Araştırmanın raporlanması süresince doğrudan alıntılara yer verilerek ve gerek araştırma süreci gerekse araştırmanın yürütüldüğü bağlam, ayrıntılı biçimde aktarılarak araştırmanın aktarılabilirliğine katkı sağlanmıştır. Ayrıca araştırmada gerek video-durumların kullanımı gerekse tartışma oturumları olmak üzere her aşamada bağlama özgü ifadeler yer almaktadır. Öğretmen adayları ile yapılan süreç değerlendirme görüşmelerinde söz konusu video-duruma 
dayalı öğretim sürecinin uygulanması aşamasına ilişkin alıntılar oldukça fazla yer almaktadır. Söz konusu ayrıntılı alıntıların yanı sıra araştırmanın raporlanması aşamasında duruma ilişkin yapılan ayrıntılı tanımlamalar ve araştırmacının süreçteki rolünün tanımlanması ile araştırmanın inanırlığına da katkı sağlamak amaçlanmıştır. Araştırma sürecinin doğası gereği bağlama özgü verilerin anlamsal bütünlüğü de göz önünde bulundurulduğundan, araştırmanın çözümleme aşaması bir araştırmacı tarafindan yürütülmüştür.

\section{Bulgular}

$\mathrm{Bu}$ bölümde araştırmanın amacına koşut biçimde, araştırmanın bulguları deneyimlerin izlenmesi ve kurgulanması, deneyimlerin tartışılması ve video-duruma dayalı öğretim sürecinin değerlendirilmesi başlıkları altında ayrıntılandırılmıştır.

\section{Deneyimlerin İzlenmesi ve Kurgulanması}

Deneyimlerin öğretmen adayları tarafından izlenmesi ve kurgulanmasına ilişkin bulgulara, sınıf-içi öğretim deneyimlerinin izlenmesi ve sınıf-içi öğretim deneyimlerinin kurgulanması başlıkları altında yer verilmiştir.

Sınıf-içi öğretim deneyimlerinin izlenmesi. Öğretmen adayları, kendilerinin sınıfiçi öğretim deneyimlerini izlemenin aşağıda maddeler halinde belirtilen yararlarından söz etmişlerdir. Kendi sınıf-içi öğretim deneyimlerini izlemeyi;

- Her öğretmenin ve öğretmen adayının yaşaması gereken bir deneyim,

- Farklı ve keyif veren bir deneyim,

- Sınıf içerisinde gerçekleşenlere yönelik farkındalık geliştirebilmeye olanak taniyan bir deneyim,

- Deneyimleri değerlendirmeye olanak tanıyan bir deneyim,

- Deneyimlerinden öğrenebilmeye olanak tanıyan bir deneyim olarak nitelendirmişlerdir.

Öğretmen adayları, araştırma sürecinde onlarla birlikte bulunmayan akranlarının (bu araştırmaya dahil olmayan diğer sınıf arkadaşlarının) da bu deneyimden yararlanmaları gerektiğini düşünürlerken bu süreçte bulunmamayı diğerleri için bir kayıp olarak görmüşlerdir. Bunların yanı sıra, meslekteki öğretmenlerin de sınıf-içi öğretim deneyimlerini izlemeleri gerektiğine değinmişlerdir. Sınıf-içi öğretim deneyimlerini izlemek, öğretmen adaylarının tamamı tarafından farklı ve keyifli bir deneyim olarak nitelendirilmiştir. Öğretmen adayları sınıf-içi öğretim deneyimlerini izlerken kendileri ve öğrenciler ile ilgili durumları fark edebilmektedirler. Kendileriyle ilgili genellikle beden dili, iletişim ve sınıf yönetimini, öğrencileriyle ilgili de sınıf-içi davranışları farketmişlerdir. Öğretmen adaylarının öğretim deneyimlerine yönelik değerlendirmelerinde, genellikle herhangi bir durumu fark etmenin ötesinde, iyi ya da kötü, doğru ya da yanlış, olumlu ya da olumsuz biçiminde kendilerini yargıladıkları görülmektedir. Benzer durumla kurgulanmış videodurumlar çözümlenirken de karşılaşılmıştır. Öğretmen adaylarının bu durumu görüş̧melerde de dile getirmiş olmaları süreç için oldukça değerlidir. Öğretmen 
adayları sınıf-içi öğretim deneyimlerini izlerken bu deneyimin onlara pek çok şeyi öğrenebilmeye olanak tanıdığını, Öğretmenlik Uygulaması ders sürecine alışmayı sağladığını, sınıf yönetimi ve öğrencilerle iletişim gibi konularda beceri geliştirdiklerini belirtmektedirler. Öğretmen adaylarına göre, kendi videolarını izlemek danışmandan alamadıkları geribildirimleri sağlamakta ve kendilerine duydukları güveni de arttırmaktadır. Tüm bunlara ek olarak öğretmen adayları, kendilerini değerlendirmenin ötesinde bir sonraki ders deneyimlerinde söz konusu durumları düzeltmeye ve iyileştirmeye odaklanmışlardır. Benzer bulgulara kurgulanmış video-durumların çözümlenmesi ile de ulaşılmış olması dikkat çekmektedir. Öğretmen adayları yansıtma ifadelerinde kurguladıkları videodurumlarda bir önceki deneyimlerinden hareketle değiştirdikleri ve iyileştirdikleri durumlara değinmişlerdir. Öğretmen adaylarının konu ile ilgili ifade örneklerinden bazılarına aşağıda yer verilmiştir.

K1: "Kendimi izlemem aslında benim için öğretmenlik açısından büyük bir tecrübeydi. Hani diğer arkadaşlarımın öyle bir imkânı yoktu, ben kendimi izledim; hani nerede, ne yanlış yaptığımı, nasıl cevap verdiğimi..."

E3: "Hali hazırda öğretmenlik yapan memurlara da bence kendini çektirmeliyiz."

K9: "Ben kendimi şanslı hissediyorum, iyi ki kendimi izleyebilmişim."

E5: "Videoda ders anlatırken bazı detayları çok kaçırmışım yani mesela öğrenci düzeyine uygunluğu çok kaçırmışım. Dersime yoğunlaşınca da sınıftaki öğrenci davranışlarını kaçırmışım. İstemediğim çok olaylar olmuş, bunları yorumlayabildim, daha sonra düzeltmeye çalışıım."

Sınıf-içi öğretim deneyimlerinin kurgulanması. Öğretmen adayları, kendilerinin sınıf-içi öğretim deneyimlerini kurgulamayla ilgili olarak aşağıda maddeler halinde belirtilen konulara değinmişlerdir. Kendi sınıf-içi öğretim deneyimlerini kurgulamayl;

- Deneyim paylaşmak,

- Eleştirilmek,

- Deneyim üzerine düşünmek/odaklanmak,

- Süreye sığdırmak alt başlıkları altında ele aldıkları belirlenmiştir.

Öğretmen adayları deneyimlerinde yer alan durumları kurgularken, tüm deneyimi izlemek ve dolayısı ile tüm deneyimi arkadaşları ile paylaşmak isterken, kurgu yaparken farklı noktaları arkadaşlarının görmesine önem verdiklerini belirtmişlerdir. Öğretmen adayları, her ne kadar farklı noktalara yer verseler de kurgulanmış video-durum materyallerinde istedikleri her duruma yer veremediklerini belirtmişlerdir. Öğretmen adaylarından bazılarının video-durum materyalini kurgularken özellikle DİOD durumlarla ilgili zorluklar yaşadıkları, bu zorlukların temelinde de olumsuz durumu başkası ile paylaşmak istememelerinin yer aldığı 
görülmektedir. Buna koşut olarak öğretmen adayları, İOD durumlara ilişkin kurgu yapmanın görece daha kolay olduğuna değinmişlerdir. Ayrıca bazı öğretmen adayları, eleştirilmek için video-durum kurgulamanın değerine vurgu yapmış ve bunu kendini gerçekleştirmek için önemli bir adım olarak değerlendirmişlerdir. Öğretmen adayları video-durumları kurgulayarak izelemenin deneyim üzerine düşünmeyi desteklediğini düşünmektedirler. Deneyimlerini akranlarının izlemesi için kurgulamak, öğretmen adaylarının deneyimlerine daha fazla odaklanmalarını sağlamıştır. Öğretmen adayları kurgulama sürecinde başlangıçta neleri eklemeleri gerektiği konusunda belirsizlik ve kararsızlık yaşarken daha sonra süreçte, açık ve anlaşılır kurgulanmış video-durum hazırlamayı öğrenmişlerdir. Bunların yanı sıra, öğretmen adaylarının iyi ya da kötü duruma ilişkin düşüncelerinin tartışma oturumlarından sonra eleştiriler doğrultusunda değişip dönüştüğü görülmüştür. Öğretmen adaylarının deneyimlerini kurgu için verilen süreye sığdırabilme konusunda zorlandıkları belirlenmiştir. Öğretmen adaylarının konu ile ilgili ifadelerinden örneklere aşağıda yer verilmiştir.

K2: "Biraz sıkıntı yaşamadım değil, şey düşündüm mesela, hani 'Arkadaşlarınki çok mu iyi olmuş acaba?' buraya gelmeden önce onu bile düşündüm. 'Ya, neyi koysam acaba? Rezil mi olurum? Çok kötü anlattım.' falan gibi şeyler düşündüm.”

E6: "Acaba burada ne yapılmalıydı, şurada ne yapılmalıydı, burada ben bunu yaptım ama burada daha farklı ne yapılabilirdi?' yorumları merak ettiğimden olabildiğince ince eleyip sik dokudum.”

E1: "Başka yerleri de arkadaşlarımın görmesini isterdim. Hani zaman kısıtlı olduğu için benim açımdan tek sıkıntısı oldu. Keşke daha fazla zamanımız olsaydı da bütün şeyi değerlendirseydik diye düşünüyordum.”

\section{Deneyimlerin Tartışılması}

Deneyimlerin tartışılmasına ilişkin bulgulara, akranlar tarafından izlenme ve değerlendirilme, akran video-durumlarının izlenmesi ve değerlendirilmesi ve akranlar ile deneyimlerin tartışılması başlıkları altında yer verilmiştir.

Akranlar tarafından izlenme ve değerlendirilme. Öğretmen adayları, kendi sınıf-içi öğretim deneyimlerinin akranları tarafindan izlenmesi konusunda, deneyimlerine yönelik yapılan değerlendirmeleri genellikle deneyimde gerçekleşen olumsuz durumlar üzerinden ele almışlardır. Öğretmen adayları, akranlarının genellikle eksik, olumsuz ya da hatalı buldukları durumlar ya da davranışlarla ilgili değerlendirmelerine odaklanmışlardır. Öğretmen adaylarının neredeyse tamamı, akranlarının, kendi deneyimlerindeki eksikleri görmelerini sağladıklarını ve akranlarının verdikleri geribildirimleri bir sonraki deneyimlerinde iyileştirmeye, dönüştürmeye ya da değiştirmeye çalıştıklarını belirtmişlerdir. Öğretmen adayları, akran geribildirimlerinde beğenilen davranışı tekrarlayarak geribildirimler sayesinde deneyimlerinin iyileştiğini ifade etmişlerdir. Akran geribildirimleri ile ilgili olarak tartışma oturumuna katılmayan devamsız arkadaşlarına değinmeleri dikkati çekmektedir. Benzer biçimde, öğretmen adaylarından bazıları da tartışma oturumlarına gelmedikleri/gelemedikleri durumlarda kendilerini kötü hissettiklerini 
belirtmişlerdir. Öğretmen adaylarının video-durumlarının akranları tarafından izleniyor ve değerlendiriliyor olmasıyla ilgili ifadelerinden hareketle, sürece yönelik güdülenmelerini öğretim sürecinin kendisinin desteklediği düşünülmektedir. Konu ile ilgili öğretmen adaylarının ifade örneklerine aşağıda yer verilmiştir.

K7: 16 kişinin gözü farklı, şöyle bir şey var biri yalnızca sınıf yönetimine bakarken biri içeriğe bakıyor biri çocukların orada ne yaptığına bakıyor. Çünkü dedim ya, $\mathrm{X}$ hocanın dediği gibi 'Ben hani 40 öğrencinin 40'ını da aynı anda gözlemleyemem.' Kim ne yapıyor arkada ya da ben arkaya döndükten sonra kim ne yapıyor onu göremem en azından bu 16 kişi ben de bir farkındalık uyandırdı.

E1: Bazı arkadaşların bazı oturumlarda eksik olması biraz etki etti. Çünkü bir oturumda 16 kişinin değerlendirmesi varken bir oturumda 11 kişinin değerlendirmesi farklı oluyor. Orada isterdim diğer arkadaşlarımın da olmasını ve benim diğer yönlerimi de belki onlar görecekti diğer arkadaşlarımın görmediği.

Akran video-durumlarının izlenmesi ve değerlendirilmesi. Öğretmen adayları, tartışma oturumlarında akranlarının kurgulanmış video-durumlarını izleyerek geribildirimlerde bulunmuşlardır. Öğretmen adaylarının, akranlarının deneyimleri ile ilgili olarak;

- Örnek almak,

- Deneyim biriktirmek,

- Gelişimlere/değişimlere odaklanmak konularına değindimişlerdir.

Öğretmen adayları, akranlarının video-durumlarında kullandıkları materyallerde, sınıf içerisinde iletişim, sınıf yönetimi gibi konularda akranlarının tavır, tutum ve davranışlarında beğendiklerini kendi deneyimlerinde uygulamışlardır. Öğretmen adayları için akran deneyimlerini izlemek en çok deneyim biriktirmek ile ilgilidir. Araştırma sürecinde yer almayan akranlarının Öğretmenlik Uygulaması dersi kapsamında bir okulda ve bir okul uygulama öğretmeni ile süreci tamamlamalarına değinen öğretmen adayları, kendilerinin daha fazla okul, uygulama öğretmeni ve sınıf-içi öğretimi gözlemlemelerini "şans" olarak değerlendirmektedirler. Öğretmen adaylarının konu ile ilgili ifade örneklerine aşağıda yer verilmiştir.

K9: İşin en paha biçilmez yanıydı çünkü şöyle bir durum vardı, her okulun öğretmeni aynı şekilde aynı kişiliğe sahip değil ve aynı davranışları sergilemiyor. Bu demek oluyor ki ben 17 farklı hocayla tanıştım. Her okulun öğrencisi aynı sosyo-ekonomik duruma sahip değil, aynı kişilik yapılarına ya da aynı çevreye sahip değil, hepsi farklı çevrelerden 17 tane çevreyle tanıştım. Sayamayacağım kadar olumsuzluklarla da karşılaşıım... aynı şey benim başıma gelseydi ne yapardım, nasıl kotarırdım diye çok fazla düşünmüş oldum ve çok fazla şeyin de farkına varmış oldum, bu yüzden güzeldi. 
Akranlar ile deneyimlerin tartışılması. Öğretmen adayları, sınıf-içi öğretim deneyimlerinin akranlarıyla tartışılması ile ilgili genellikle geribildirimlere odaklanmışlardır. Öğretmen adayları tartışma oturumlarında;

- Geribildirimlerin ve eleştirilerin içeriği,

- Geribildirimlerin ve eleştirilerin niteliği,

- Geribildirimlerin ve eleştirilerin gelişimi ile ilgili konulara değinmişlerdir.

Tartışma oturumlarında, öğretmenin ders öncesi durumu, okul idaresinin tutumu, sınıfın önceki durumundan ders sonrası durumuna kadar pek çok konunun geribildirimlerin içeriğini oluşturmaktadır. Öğretmen adaylarından bazıları daha çok ders sırasında olanlara odaklanmaları gerektiğini, bazıları da süreç ile ilgili pek çok şeyin sınıf içerisinde olanları etkileyebildiğini düşünmektedirler. Geri bildirimlerin niteliğiyle ilgili genellikle olumlu ifadelere yer vermiş ve yapılan eleştirilerde kişisel ilişkilerin ön planda olmadığını, eleştirilerin saygı çerçevesinde ve yapıcı olduğunu vurgulamışlardır. Öğretmen adayları en çok geribildirimlerin gelişimine vurgu yapmışlardır. Öğretmen adaylarının tamamının bu konuda ortak bir görüşe sahip oldukları, başlangıçta akranları tarafından yapılan eleşitirileri kişisel ve incitici olarak algılamalarına karşın, süreçte hem eleştirmeyi hem de eleştirilmeyi öğrendikleri görülmüştür. Ayrıca öğretmen adayları geribildirim vermeyle ilgili beceri geliştirmişlerdir. Öğretmen adaylarının konu ile ilgili ifadelerinden bazılarına aşağıda yer verilmektedir.

$\mathrm{K} 1$ : "İlk yorumlar yapıldığında insan ister istemez kendi üzerine alınıyor, bozuluyor, o yüzden kızıyordum, not alıyorum, işte söyleyeceğim bunları diye. Onu aştığımı düşünüyorum artık, eleştiriler daha iyi olmam için, çekidüzen vermem için.”

E7: "Mesela hiç alışkın olmadığım bir şey yaptım burada, bir hareketim, bir davranışım, bir cümlem için 16 kişinin eleştirisini dinlemek gerçekten kolay bir şey değil... 16 kişinin fikrine çok ihtiyaç var ama eleştirileri almak ilk videoda bana çok zor geldi."

\section{Video-Duruma Dayalı Öğretim Sürecinin Değerlendirilmesi}

Öğretmen adayları ile araştırma sürecine ilişkin süreç değerlendirme görüşmeleri yapılmıştır. Bu bölümde, söz konusu bu görüşmelerden elde edilen veriler aşağıda aktarılmaktadır.

- Sürece katılma,

- Süreç öncesi hazırlıklar (Yapılan açıklamalar, yapılan program ve programa uyma, işbirliği ve iletişim),

- Teknik araç-gereç,

- Teknik anlamda kurgu yapma (Yapılan açıklamalar, süre ve yönerge, Kullanılan program),

- Tartışma oturumları (Tartışma oturumlarının süresi, tartışma oturumlarının düzenlenmesi), 
- Süreçte duygu ve güdülenme (Kamera önünde olmak, en olumlu duygu, en olumsuz duygu, süreçte güdüleyen şey),

- Sürece kattıkların ve sürecin sana kattıkları,

- Benzer bir çalışmada bulunmaya isteklilik.

Öğretmen adayları çalışmanın kendileri için yararlı olacağını düşündükleri ve çalışmayı merak ettikleri için sürece katılmışlardır. Bazı öğretmen adayları, süreç öncesinde endişe duyduklarını belirtirlerken bazıları ise çalışmaya katılım önerisi geldiğinde kendilerini özel hissettiklerini belirtmişlerdir. Konu ile ilgili öğretmen adaylarının ifadelerinden biri (K8) şöyledir: "Böyle bir projede yer almanın bana bir şeyler katabileceğini düşündüm, yani en temel sebebi buydu, hani kendimi geliştirmeme olanak sağlayacaktı, ben sağlayabilir diye adım attım, aslında biraz bencillik yapıp kendim için istedim."

Sürece yönelik düzenlenen seminerin içeriğiyle ilgili, öğretmen adaylarının büyük çoğunluğu sürece yönelik açıklamaları yeterli bulurken uygulama aşamasında iyileştirilmesi gereken bazı noktalar olduğunu belirtmişlerdir. Öğretmen adaylarından bazıları, yapılan açıklamaların yetersiz olduğunu düşünmekte ve özellikle süreç boyunca gereken süre hakkında yeterince bilgi verilmediğinden şikâyet etmektedirler. Öğretmen adaylarının tamamı süreç öncesinde hazırlanan zaman çizelgesini her ne kadar etkili bulsalar dahi sürecin yoğun olduğunu düşünmektedirler. Öğretmen adayları, süreçte işbirliği ve iletişim ile ilgili olarak herhangi bir aksaklık yaşamadıklarına, işbirliği içerisinde ve diğerlerine yardımcı olacak biçimde çalıştıklarına vurgu yapmışlardır. Bunun yanı sıra, süreçte kullanılan anlık iletişim uygulamasından (WhatsApp) oldukça etkin yararlanıldığına değinmişlerdir. Öğretmen adaylarının konu ile ilgili ifadelerinden bazılarına aşağıda yer verilmektedir.

K3: "Açıkçası çok yeterli olduğunu düşünmüyorum hocam, 'Üç toplantı yapacağız.' Demiştiniz, ben yalnızca üç toplantı sanmıştım ve en fazla ikiş̧er saat sürer zannetmiştim. Bu kadar uzun süreceğini, bu kadar vakit alacağını bilmiyordum.”

K9: "Genel olarak çok iyiydi, zaten WhatsApp grubunda işleyiş de çok iyiydi, herkes her şeyden haberdardı, o konuda bir sıkıntı yoktu. Siz de gayet her şeyden haberdar ettiniz, o yüzden herkes sorumluluğunu yerine getirdi."

Öğretmen adaylarının tamamı, video kameraları sayı, hafıza, batarya, görüntü kalitesi ve ses kalitesi açısından yeterli gördüklerini belirtmişlerdir. Sayıca fazla olmamasına karşın, kameraların kullanımında sorun yaşanmamasında önceden yapılan planlamaya değinmişlerdir. Bunlara ek olarak, öğretmen adaylarından bazıları kameranın varlığının sınıftaki öğrenciler için dikkat dağıtıcı bir öğe durumuna geldiğini, bazı öğretmen adayları da kalabalık ve gürültülü sınıflar için ses kayıt gücü daha yüksek video kameraların kullanılmasının daha iyi olabileceğini belirtmişlerdir.

K2: Teknik ekipman bence yeterliydi, hani çekmesi, sınıf içerisine yerleştirilmesi... Süre bakımından bir sıkıntı yaşamadık, bataryalar 
falan yetti, hafıza olarak da birbirimize hiç sıkıntı, hani şöyle bir sıkıntı yetmedi ya da kamera olmadığı gibi bir sıkıntı olmadı... Sayı bakımından da yeterliydi.

$\mathrm{K} 7$ : Bu şey ses konusunda eğer gerçekten mikrofon gibi bir şey olmuş olsaydı daha iyi olabilirdi. Çünkü arkadaki insanların sesleri çıkıyordu, öğrencilerin sesi çıkıyor, aslında bizim tarafta olduğumuz için hepsini duyamıyoruz ama kamerada izlediğimizde daha fazla ses çıkıyor ama biz bunu sınıf içerisinde fark edemiyoruz.

Öğretmen adaylarının büyük çoğunluğu video-durum kurgulamaya ilişkin yapılan açıklamaları yeterli bulmuşlardır. Öğretmen adayları, her ne kadar açıklamaları yeterli bulduklarını belirtseler de kurgu yapmayı düzeltme ve düzenlemelerle süreçte öğrendiklerine vurgu yapmışlardır. Öğretmen adayları deneyimlerini kurgulayabilmeleri için verilen sürelerin, onların kurgulama süreçlerini ya da hazırlanan video-durumların niteliğini etkileyip etkilemediğine yönelik olarak genellikle verilen sürenin hem video kurgulama sürecini hem de niteliğini etkilemediğini belirtmişlerdir. Öğretmen adaylarının konu ile ilgili ifadelerinden bazılarına aşağıda yer verilmiştir.

K9: Biz BÖTE'de olmasaydık açıklamalarınız çok yetersizdi tırnak içerisinde ama siz bizim alt bilgilerimize, önbilgilerimize güvendiğiniz için 'Arkadaşlar 10-15 dakikalık kısa bir film tarzında bir video istiyorum, eleştirilerinizde ya da beğenilerinizi yazı şeklinde içinde ifade edin.' dediniz. Bu açıklama biz BÖTE'ci olduğumuz için yeterliydi, bu bağlam için yeterliydi ama başka branşlar için kesinlikle değildi.

K4: Ben yaptığını düşünmüyorum. Çünkü konacak şeyler belliydi kurgu yapmak bence o kadar da zor bir iş değildi yani benim için. Çünkü bağlamı takip ediyorsun, burada bir olay oldu bunu koy ama devamını da yaz, kes koy böyleydi benim için kolaydı.

Öğretmen adayları video-durum kurgularken Movie Maker, Adobe Premiere Pro ve Camtasia Studio olmak üzere üç farklı video düzenleme programından yararlanmışlardır. Öğretmen adayları tarafından en çok tercih edilen Movie Maker; oldukça kullanıcı dostu hemen her bilgisayar kullanıcısının kullanımına uygun, kesme, bölme, yazı ekleme gibi temel işlevleri yerine getirebilen ancak tasarım için genellikle ekranın bölünmesi biçiminde kullanılabilen bir video düzenleme programıdır. Öğretmen adayları, kullandıkları işletim sistemi ile birlikte verilmesi, kullanımı kolay olması, yapacakları iş için yeterli olması nedeni ile söz konusu bu programı tercih etmişlerdir. Öğretmen adayları tarafından yaygın kullanılan bir diğer video düzenleme programı ise Camtasia Studio; tüm bu özelliklerden farklı, görüntü yakınlaştırma, anlık ve görsel ögeleri daha gelişmiş biçimde metin eklemeye olanak tanıma ve video izlerken düzenleme yapabilme özelliklerine sahip bir video düzenleme programıdır. Bu programı tercih eden öğretmen adayları genellikle görüntü yakınlaştırma özelliği ve kolay kullanımı için tercih ettiklerine 
değinmişlerdir. Öğretmen adaylarından biri (E3) bu programlardan farklı ve görece daha fazla teknik bilgi ve beceri gerektirebilecek ve görece daha karmaşı düzenlemeler yapmaya olanak tanıyan Adobe Premiere Pro kullanarak video-durum materyali oluşturmuştur. Konu ile ilgili öğretmen adaylarının görüşlerinden birisi (E4) "Özel bir sebebi yoktu, dediğim gibi yoğunluk sebebiyle farklı, biraz daha kolay ve bildiğim bir programdı. Diğerlerine o yüzden yönelmek istemedim aslında öğretim tasarımı dersinde farklı programlarda kullanmıştık ama daha kolay olduğu için bunu seçtim" biçimindedir.

Sürecin öğretmen adayları için özveri gerektiren bölümlerinden belki de en önemlisi tartışma oturumlarıdır. Süreçte 16 öğretmen adayı için toplam 48 sınıf-içi öğretim deneyimi ile hazırlanmış video-durumların izlenmesi ve tartışılması söz konusu olduğundan, tartışma oturumları sürecin başında olması beklenenden fazla zaman almıştır. $\mathrm{Bu}$ durum, süreç değerlendirme görüşmelerinde öğretmen adayları tarafından da dile getirilmiştir. Öğretmen adayları, tartışma oturumlarının yoğunluğuna vurgu yaparlarken sürenin uzamasının tartışmanın doğasından kaynaklandığına, belki de çoğu noktanın daha da uzun tartışılması gerektiğine değinmişlerdir. Süreçte özellikle ilk hafta yapılan tartışma oturumları planlanandan uzun sürdüğünden, oturumların süresi için müdahalede bulunulmuş ve her bir videodurum için tartışma süresi sınırlandırılmıştır. Öğretmen adayları, süre sınırlamasının iyi bir çözüm olduğunu belirtseler de tartışmaların niteliğini etkilediğini düşünmektedirler. Bunun yanı sıra öğretmen adayları, tartışma oturumlarında özellikle ilk izlenen video-durum materyallerinin görece daha şanslı olduğunu belirtmişlerdir. Bu durumu, tartışmaların yoğunluğu ve yorgunluk düzeyinin artması ile ilişkilendirmişlerdir. Konu ile ilgili öğretmen adaylarının ifadelerinden örneklere aşağıda yer verilmiştir.

K3: "İlk üç videonun şanslı videoları olduğunu düşünüyorum video sahipleri için. Bunun dışında olumsuzluk süre ve zaman sıkıntısı dışında farklı bir olumsuzluk yaşadığımızı düşünmüyorum."

E2: Aksaklık derken evet, biraz uzun sürdü, çok fazla toplantı saatleri uzun sürdü; videolar, kameralar, kurgular biraz zamanımızı aldı... Zamanımızı aldı yani özel hayatımızdan çok zamanımızı aldı öyle söyleyeyim, özellikle ben kendi açımdan söyleyeyim, öyle yani başka bir sıkıntı yaratmadı yalnızca özel olarak.

Öğretmen adayları, deneyim değerlendirme döngüsünün üç kez gerçekleştirilmesi ile ilgili olarak sürecin yoğunluğu göz önünde bulundurulduğunda, katılımcı sayısının daha az olduğu durumlarda daha çok tekrarla yapılmasının daha yararlı olabileceğini düşünmektedirler. Sürecin bir kez uygulanmasının hataları görmek için yeterli olacağı ancak gelişim için yeterli olmayacağına değinirken üç tekrar ile yeterince deneyim görülebileceğini, üçten fazla olmasının daha çok pekiştirmeye yarar sağlayacağını belirtmişlerdir. Sınıf-içi öğretim deneyimlerinin süreçte kayıt altına alınması ve sınıfta video kameranın varlığı, öğretmen adaylarını ilk anlatımlarında tedirgin hissettirse de süreç ilerledikçe kendilerinin bu duruma 
alıştıkları görülmüştür. Öğretmen adaylarının konu ile ilgili ifadelerinden örneklere aşağıda yer verilmiştir.

K8: Acaba daha mı az kişiyle yapsaydık? Hani daha mı az kişi olsaydı? Ama bu sefer de daha zengin bilgiler elde edemeyecektik o da var. Ama sanki daha az kişiyle olsaydı, atıyorum bu süreç bir gün olsaydı insanlar daha verimli katılırlar mı acaba diye düşünüyorum.

E1: Böyle bir kamera ortamında videolarda çıkmayı pek fazla sevmem. Hoşlanmıyorum, kendimi kötü hissediyorum o yüzden ilk zamanlarda heyecanım vardı... Alıștım hocam, evet kendime bir özgüven geldi, ilk zamanlar böyle değildim... İlk anlatımımda heyecanım çok fazlaydı kamera çektiği için ama diğer anlatımlarda buna alıştım... Daha da fazla çekilmesini ister oldum.

Öğretmen adayları süreçte kendilerini izleme, hem kendilerinde hem de arkadaşlarındaki değişimi fark etme, eleştirme ve eleştirilme konusunda gelişme, akranları tarafindan beğenilme ve fikirlerinin önemsenmesi konularında olumlu hislerden söz etmektedirler. Öğretmen adaylarından bazıları sürece yönelik olumsuz herhangi bir duygu hissetmezken bazıları arkadaşları tarafından eleştirilmekten rahatsız olmuşlardır. Öğretmen adayları, fakültedeki dersler, uygulama okulundaki dersler ve bunların dışında KPSS (Kamu Personel Seçme Sınavı) sınavı için dershaneye devam etme ve sınava hazırlık süreci gibi nedenlerle süreçte zorlanmışlardır. Bunların dışında öğretmen adayları, süreçte akranlarının deneyimlerini izleyebilme ve değerlendirebilmenin, kendilerini izleme ve değerlendirmenin, deneyimdeki değişimi ve gelişimi görmenin güdülenmelerine destek sağladığına değinmişlerdir. Bunların yanı sıra öğretmen adayları, en çok sürecin etkili, verimli ve çekici bir süreç olduğunu düşünmektedirler. Öğretmen adaylarının konu ile ilgili ifadelerinden örneklere aşağıda yer verilmiştir.

K1: "Güdüleyen şey, dediğim gibi o videolarda aslında değişik olayları görmek güzeldi, ondan dolayı merak ederek geliyordum. Buydu beni güdüleyen, meraktı beni güdüleyen."

E3: "Görüşmeler esnasında da bayağı bir eğlendiğimi söyleyebilirim ya... Özleyeceğim hani özlemeyeceğim değil öyle... teşekkür ederim süreç genel olarak benim için tatmin ediciydi... bitiyor olması üzücü benim için."

Öğretmen adayları, sürece gerek deneyimleri gerekse tartışma oturumları ile birçok şey kattıklarını belirtmişlerdir. Öğretmen adayları, iyi, donanımlı sınıf örneği, sınıf yönetimi ile ilgili izlenen yol, sınıf içi ses düzeyinde tolerans gibi konularda sürece deneyim çeşitliliği; sınıf-içi disiplin, eşitlik ve cinsiyet eşitliği, içerik bilgisi ve öğrenci bakış açısı gibi konularda eleştiri çeşitliliği sağlamışlardır. Öğretmen adayları uygulanan öğretim süreciyle deneyimlerinin değiştiğini, tartışmayı öğrendiklerini, eleştiri kabul etme becerisi geliştirdiklerini, deneyimleri üzerinde düşünebilmeyi öğrendiklerini ve hatta kimi zaman stajda okul rehber öğretmenlerinden alamadıkları geribildirimleri aldıklarını belirtmişlerdir. Öğretmen adayları, sürecin işbrlikli 
çalışma ve takım ruhu geliştirebilmeye olanak tanıdığını belirtmişlerdir. Bunların yanı sıra öğretmen adayları, süreçte mesleki anlamda etkili anlatma becerisi, öğrenciyle iletişim ve etkileşim becerisiyle öğretme işine ve uygulama sürecine yönelik farkındalık kazandıklarını belirtmişlerdir. Öğretmen adaylarını tamamı kendilerinden beklenenlerin benzer olduğu bir çalışmada bulunmak isteyebileceklerini açıklamışlardır. Bazıları, daha az kişi ile tasarlanan bir süreçte biraz daha deneyim kazandıktan sonra ve gerekli şartlar sağlandığında tekrar böyle bir çalışmaya katılmayı isteyebileceklerini belirtmiştir. Öğretmen adaylarının konu ile ilgili ifadelerinden örneklere aşağıda yer verilmiştir.

K4: "Ben bu çalışmaya çok şey kattım, bir kere farklılı̆̆ım olduğunu düşünüyorum, onu ortaya koydum. Birçok arkadaşım sessizlikten hoşlanıyordu ki ben o kadar sessizliği sevmiyorum."

E2: "İsterim çünkü bana bir şeyler katıyor, hani ben öğretmen olacaksam da bir şeyler katıyor, akademisyen olacaksam yani bir şeyler katıyor."

\section{Tartışma, Sonuç ve Öneriler}

Öğretmen adaylarının kendi sınıf-içi öğretim deneyimlerini kurgulamalarını ve söz konusu bu videolar üzerinden akranları ile tartışmalarını içeren video-duruma dayalı öğretim sürecinin değerlendirilmesi amacıyla yapılan araştırmada, öğretmen adaylarının tamamının süreçte kendilerini izleme, deneyimleri üzerine düşünme, deneyimlerini kurgulama ve deneyimlerini akranları ile tartışmaya ilişkin olumlu görüş bildirdikleri görülmektedir. Öğretmen eğitiminde, öğretmen adaylarının izledikleri sınıf-içi etkileşimleri fark edilebilmeleri oldukça büyük öneme sahiptir (Sun ve van Es, 2015). Video-duruma dayalı öğretim uygulamalarıla öğretmen adaylarının, öğrencilerin sınıf içerisinde diğer öğrencilerle ve öğretmen olarak kendileriyle etkileşimlerini fark etme becerilerini geliştirmek olanaklıdır (Eilam ve Poyas, 2006; Høynes ve diğ., 2019; Keppens, Consuegra, Goossens, De Maeyer ve Vanderlinde, 2019; König ve diğ., 2014; Rosaen, Lundeberg, Cooper, Fritzen ve Terpstra, 2008; Stockero ve diğ., 2017; Xiao ve Tobin, 2018; Yeh ve Santagata, 2015). Öğretmen adaylarının video-durumları akranları ile işbirlikli değerlendirmeleri, sınıfiçi öğretim deneyimlerine ilişkin farkındalıklarını geliştirmektedir (Nielsen, 2015). Benzer biçimde, Grant ve Kline (2010) tarafindan yapılan bir araştırmada videodurumlar ve tartışmaya dayalı öğretim sürecinin bireysel farkındalığı geliştirdiği gözlemlenmiştir. Video-duruma dayalı öğretim yönteminin kullanıldığı çalışmaların pek çoğunun doğrudan odağında yer alan fark etmenin; öğretmen adaylarının kendileri tarafından da ifade edilmiş olması ve bunun onlar tarafından da değerli bulunması araştırma süreci için oldukça önemli bir yere sahiptir. Öğretmen adaylarının sınıf-içi öğretim deneyimlerini izlemeye yönelik ifadeleri, kurgulanmış video-durumların çözümlenmesine ilişkin bulgularla koşutluk göstermektedir. Öğretmen adaylarının kendi deneyimlerini izlerken edindiklerini düşündükleri farkındalık geliştirme, deneyimleri değerlendirme ve deneyimlerden öğrenme becerileri, geliştirdikleri video-durum materyallerine de yansımıştır. Buradan hareketle öğretmen adaylarının kendi öğretim deneyimlerini izleme ile başlayan bu 
sürecin, bireysel farkındalıklarının gelişimine yönelik önemli katkılar sağladığı söylenebilir.

Öğretmen adaylarının kendi sınıf-içi öğretim deneyimleri üzerinden özdeğerlendirme becerileri, uzmanlık geliştirebilmeleri için oldukça önemli bir özellik olarak nitelendirilmektedir (Koorland ve diğ., 1985). Öğretmen adaylarının özdeğerlendirme konusunda yetiştirilmesi ve öz-değerlendirme becerisi geliştirmelerinin desteklenmesi meslek yaşamlarında öğretim ile ilgili karşılaşabilecekleri zorluklarla başa çıkabilmelerinde yarar sağlamaktadır (Miyata, 2002; Rich ve Hannafin, 2008). Ayrıca öğretmen adaylarının deneyimledikleri otantik video-durumları kullanmak, deneyimlerini arttırmak ve gerçek yaşamdaki problem çözme becerilerini geliştirmek için büyük öneme sahiptir. Öğretim sürecinde başarılı ve başarısız durumlardan yararlanma, öğretmen adaylarının problem çözme becerilerini geliştirmektedir (Rong ve Choi, 2019). Benzer biçimde bu araştırmaya katılan öğretmen adayları kendi sınıf-içi öğretim deneyimlerini izleyebilme ve bu deneyimler üzerine düşünebilme olanağı buldukları için kendilerini şanslı hissettiklerini belirtmişlerdir. Öğretmen adayları sürecin başlangıcında her ne kadar video-durum materyali oluştururken değerlendirmede yetersiz olduklarını ifade etseler de süreç ilerledikçe durum değerlendirmeye ilişkin deneyim ve beceri geliştirmişlerdir.

Öğretmen adayları, kendilerinin sınıf-içi öğretim deneyimlerini izlemeleri ve kurgulamalarıyla ilgili her öğretmenin ve öğretmen adayının yaşaması gereken, farklı ve keyif verici, sınıf içerisinde gerçekleşenlere yönelik farkındalık geliştirmeyi sağlayan, deneyimleri değerlendirmeye ve deneyimlerden öğrenebilmeye olanak tanıyan bir süreç yaşadıklarını ifade etimişlerdir. Benzer biçimde alanyazında, öğretmen adaylarının kendi deneyimlerini izlemelerinin ve kurgulamalarının, yaparak yaşayarak öğrenmelerini desteklediği ve öğretim sürecine yönelik güdülenmelerini arttırdığı belirtilmektedir (Cid-Cid, Guede-Cid ve Tolmos-Rodríguez-Piñero, 2018; Koç, 2011; Olivero, John ve Sutherland, 2004; Rosaen ve diğ., 2009; Yeh, 2018). Beisiegel, Mitchell ve Hill (2018) tarafından yapılan bir araştırmada, kendilerinin sınıf-içi öğretim uygulamaları üzerinden tasarlanan video-durum izleme etkinliklerinin, öğretmen adaylarının öğretim deneyimlerinden öğrenebilmeleri için açık ve somut bir köprü görevi gördüğü ifade edilmektedir.

Sınıf-içi öğretim deneyimlerinin akranlar tarafindan izlenmesi ve değerlendirilmesi, öğretmen adaylarının bireysel farkındalıklarını arttırmaya destek olmakta ve öğretmen adayları sonraki deneyimlerini akran geribildirimleri ile yapılandırarak iyileştirdiklerini ifade etmektedirler. Benzer biçimde, akranlar tarafından yapılan video geribildirimlerin mesleki davranışları etkileyebileceği ifade edilmektedir (Brouwer, Besselink ve Oosterheert, 2017). Ayrıca öğretmen adaylarının beceri geliştirmelerinin, geliştirilen becerilerin sınıf-içi öğretim süreçlerine aktarılma düzeyi üzerinden anlam kazanbileceği üzerinde de önemle durulmaktadır (Weber, Gold, Prilop ve Kleinknecht, 2018). Dahası, öğretmen adaylarının deneyimlerinin akranları tarafından izleniyor ve değerlendiriliyor olmasıyla ilgili ifadelerinden 
hareketle uygulanan öğretim yönteminin, kendisinin sürece yönelik güdülenmelerini desteklediği düşünülmektedir.

Öğretmen adaylarının kendi video-durumlarının yanı sıra akranlarının videodurumları kullanılarak tasarlanan duruma-dayalı öğretim sürecinde, akran videodurumları aracılığı ile öğretim sürecinde içerik çeşitliliği ve öğretmen adaylarının daha fazla sınıf-içi durum örneğine ulaşması sağlanmaktadır (Brunvand, 2010; Kucan, Palincsar, Khasnabis ve Chang, 2009; Olkun, ve diğ., 2009; Shen, Gromova, Zakirova ve Yalalov, 2017; Yung ve diğ., 2007). Akranlarının sınıf-içi öğretim uygulamalarını izlemek, öğretmen adaylarının deneyim eksikliklerini giderebilmelerini sağlamanın yanı sıra, diğerlerinin deneyimlerinden öğrenmelerine de destek olmaktadir (Barth, Piwowar, Kumschick, Ophardt ve Thiel, 2019; de Mesquita, Dean ve Young, 2010; Rong ve Choi, 2019; Roose, Goossens, Vanderlinde, Vantieghem ve Van Avermaet, 2018; Sherin ve Van Es, 2009; Stockero, 2008; Van den Berg, 2001). Ayrıca akranlarının öğretim deneyimleri aracılı̆̆ı ile öğrenme süreci, öğretmen adaylarının öğretim sürecine ilişkin güdülenmelerini arttırmaktadır (Sharpe ve diğ., 2003). Akran deneyimlerini izlemek ile ilgili olarak, öğretmen adaylarının süreçte akranlarındaki değişim ve gelişimi fark ettiklerine yönelik açılamalarda da bulundukları belirlenmiş̧tir. Öğretmen adayları süreçte diğerlerinin deneyimlerindeki değişimlerin, onları gerek süreç açısından gerekse mesleki deneyim açısından güdülediğini belirtmiş̧lerdir. $\mathrm{Bu}$ araştırmaya katılan öğretmen adayları akran deneyimlerinin izlenmesi ile ilgili olarak, öğretmen adayları tarafindan örnek alma, deneyim biriktirme ve deneyimlerdeki gelişim ve değişimler üzerinden ele alınırken öğretmen adaylarının akranlarının sınıf-içi öğretim deneyimleriyle ilgili olarak en çok deneyim biriktirmeye odaklandıkları görülmüştür. Doerr ve Thompson tarafindan (2004) yapılan bir araştırmada, video-durumlar öğretmen adaylarına matematiksel kuramsal bilginin uygulamada nasıl öğretilebileceğine ilişkin örnek sağlamak amacıyla kullanılmıştır. $\mathrm{Bu}$ araştırmanın katılımcıları olan öğretmen adayları da deneyimleyemeyecekleri kadar öğretim durumu örneği gözlemlemenin kendilerine katkı sağladığına vurgu yapmışlardır. Söz konusu araştırma bulgusu, video-duruma dayalı tasarlanan öğretim süreçleri ile öğretmen adaylarına deneyim biriktirebilmeleri için görece daha fazla olanak tanıyabilmeye ilişkin alanyazınla koşutluk göstermektedir (Kucan ve diğ., 2009; Shen ve diğ., 2017; Sun ve van Es, 2015). Benzer biçimde video-duruma dayalı öğretim yöntemi, sınıf-içi öğretim deneyimleri öncesinde ya da sırasında öğretmen adaylarının diğerlerinin deneyimlerinden öğrenebilmelerini de desteklemektedir (Beisiegel ve diğ., 2018).

Video-duruma dayalı tasarlanan öğretim sürecinde ve yüzyüze ortamda gerçekleşitirilen tartışma oturumlarında, öğretmen adaylarının geribildirimlerin içeriği, niteliği ve gelişimine odaklandıkları görülmüștür. Öğretmen adayları, tartışma oturumlarında verilen geribildirimlerin niteliğinin geliştiğine değinirlerken süreçte en çok eleştirme ve eleştirilme konusunda gelişim gösterdiklerine vurgu yapmışlardır. Nielsen (2015) tarafından yapılan bir çalışmada, öğretmen adaylarının süreçte giderek ileri düzey çözümleme becerisi geliştirdiklerine ilişkin elde edilen bulgular, bu araştırmanın bulgularıyla benzerlik göstermektedir. Ayrıca ilgili alanyazında, 
yapılandırılmış video-durum çözümleme süreçleriyle, öğretmen adaylarının öğretimin karmaşıklığını farketmeleri ve belirli çc̈zümleme görevleri aracılığıyla daha derin eleştirel yansıtma becerileri geliştirebilmelerinin olanaklı olduğu yönünde kanıtlara ulaşılmıştır (Coffey, 2014; Maclean ve White, 2007; Rhine ve Bryant, 2007).

Öğretmen adaylarının sınıf-içi öğretim deneyimlerine ilişkin açıklamalarında değindikleri üzere, fakültedeki kuramsal derslerde öğrenilenlerin okul deneyimi sırasında uygulamaya aktarılabilmesi kolay değildir; bunun için daha fazla uygulama olanağına gereksinimleri vardır. Benzer biçimde Miller (2009) tarafindan yapılan bir araştırmada, öğretmen adaylarının en çok sınıf-içi öğretim uygulamalarındaki deneyimsizlik konusunda sorun yaşadıkları, üniversitede öğrenilen kuramsal bilgi ile okulun beklentilerinin uyuşmadığı ve bu durumun uygulama sürecinde sorunlara yol açtığ 1 belirlenmiştir. Öte yandan, bu araştırmaya katılan öğretmen adaylarının araştırma sürecini değerlendirmeye ilşikin görüşleri, yaşadıkları sorunların giderilmesinde video-duruma dayalı tasarlanan öğretimin destekleyici bir role sahip olduğunu göstermiştir.

Öğretmen adaylarının teknik bilgi ve becerilerinin düzeyi uygulanan süreci doğrudan etkileyebilmektedir. $\mathrm{Bu}$ araştırmaya katılan öğretmen adaylarının alanlarının BÖTE olması nedeniyle video-düzenleme programlarına ilişkin önbilgi düzeyleri yüksektir. Araştırma sürecinin başında öğretmen adaylarına eğitim düzenlenmek istenmesine karşın, gereksinim duymadıkları gerekçesi ile tasarlanan eğitimin gerçekleştirilmediğini ayrıca belirtmek gerekmektedir.

Video-duruma dayalı öğretim sürecine ilişkin yapılan en önemli geri bildirim, katılımcıların sayısı ve uygulama süresi ile ilgilidir. Öğretmen adayları, katılımcı sayısının çok olmasının edinilen farklı deneyimle doğrudan ilişkili olduğunu ifade ederlerken aynı durumun sürecin zaman olarak yoğunluğuyla da ilişkili olduğunu belirtmektedirler. $\mathrm{Bu}$ durumun en uygun biçimde düzenlenmesinin ya da tartışma oturumlarının sürecin başlangıcında sınırlarının ayrıntılı olarak belirlenmesinin uygulama sürecine ve süreçten elde edilecek yarara katkı sağlayacağına vurgu yapmaktadırlar.

\section{Öneriler}

Öğretimsel karar alma sürecinde, deneyimin önemli bir role sahip olmasına koşut biçimde, video-duruma dayalı öğretim süreçleriyle öğretmen adaylarına yalnızca Okul Deneyimi ve Öğretmenlik Uygulaması dersleri bağlamında deneyimleyebileceklerinden çok daha fazla şehir, okul, sınıf ve öğrencilerden oluşan diğerlerinin deneyimlerini aktarmak ve bu deneyimler üzerinden "rutinler/alışkanlıklar" geliştirmelerini sağlamak olanaklıdır.

Araştırmada yürütülen video-duruma dayalı öğretim sürecinde öğretmen adayları etkin katılımcılar olarak rol almakta ve öğretim sürecinin merkezinde kendi sınıf-içi öğretim deneyimleri yer almaktadır. Söz konusu süreç, öğretmen adayları tarafindan her ne kadar emeğin yoğun olduğu bir süreç olarak değerlendirilse de süreç 
sonunda öğretmen adaylarının tamamı, sürece devam etme ve yeniden benzer süreçlerde yer almaya ilişkin olumlu görüş bildirmişlerdir. Söz konusu bu olumlu değerlendirmelerden yola çıkarak uygulanan video-duruma dayalı öğretimin, öğretmen adayları için güdülenme kaynağı olduğu söylenebilir. Benzer uygulamalar, öğretmen eğitiminde farklı disiplin alanları için de kullanılabilir.

Araştırma sürecinde uygulanan video-duruma dayalı öğretim sürecinin, katılımcı sayısının fazla olduğu durumlarda zaman maliyetini arrtıracağı göz önünde bulundurulmalıdır. Katılımcı sayısının görece fazla olduğu durumlarda öğretim süreci tasarlanırken özellikle tartı̧̧malar yüz yüze ortam yerine çevrimiçi ortamda ya da bütünleşik biçimde tasarlanarak uygulama süreci yapılandırılabilir.

$\mathrm{Bu}$ araştırmada öğretmen adaylarının kendi sınıf-içi öğretim deneyimlerini kendilerinin kurguladığı bir öğretim süreci tasarlanmıştır. Video kurgulamanın, öğretmen adaylarına sağlayacağı yararın ortaya konması alanyazına ayrıca yarar sağlayacaktır. Öğretmen adaylarının kendi sınıf-içi öğretim deneyimlerini kendilerinin kurgulamaları ile araştırmacı ya da uzman öğretmenler tarafindan kurgulanmasının öğretim sürecine etkisinin incelenmesi alanyazına katkı sağlayabilir.

\section{Kaynakça}

Arkün-Kocadere, S. A. ve Aşkar, P. (2013). Okul uygulamaları derslerine ilişkin görüşlerin incelenmesi ve bir uygulama modeli önerisi. Hacettepe Üniversitesi Ĕ̈itim Fakültesi Dergisi, 28(2), 27-43. http://www.efdergi.hacettepe.edu.tr/shw_artcl-165.html adresinden edinilmiştir.

Arıc1, B. (2007). Bilgisayar ve ögretim teknolojileri eğitimi bölümü ögrrencilerinin mesleğe yönelik beklentileri ile alanda çalışan bilgisayar öğretmenlerinin mesleğe yönelik algıları. (Yayımlanmamış yüksek lisans tezi). https://tez.yok.gov.tr/UlusalTezMerkezi/'nden edinilmiştir (Tez No. 215794).

Averill, R., Drake, M., Anderson, D., and Anthony, G. (2016). The use of questions within in-the-moment coaching in initial mathematics teacher education: Enhancing participation, reflection, and co-construction in rehearsals of practice. Asia-Pacific Journal of Teacher Education, 44(5), 486-503. doi: 10.1080/1359866X.2016.1169503

Baecher, L., Kung, S., Jewkes, A. M., and Rosalia, C. (2013). The role of video for self-evaluation in early field experiences. Teaching and Teacher Education, 36, 189-197. doi: 10.1016/j.tate.2013.08.001

Barth, V. L., Piwowar, V., Kumschick, I. R., Ophardt, D., and Thiel, F. (2019). The impact of direct instruction in a problem-based learning setting. Effects of a video-based training program to foster preservice teachers' professional vision of critical incidents in the classroom. International Journal of Educational Research, 95(1), 1-12. doi: 10.1016/j.ijer.2019.03.002 
Beisiegel, M., Mitchell, R., and Hill, H. C. (2018). The design of video-based professional development: An exploratory experiment intended to identify effective features. Journal of Teacher Education, 69(1), 69-89. doi: $10.1177 / 0022487117705096$

Brouwer, N., Besselink, E., and Oosterheert, I. (2017). The power of video feedback with structured viewing guides. Teaching and Teacher Education, 66, 60-73. doi:10.1016/j.tate.2017.03.013

Brunvand, S. (2010). Best practices for producing video content for teacher education. Contemporary Issues in Technology and Teacher Education, 10(2), 247-256. Retrieved from https://www.citejournal.org/volume-10/issue-2-10/currentpractice/best-practices-for-producing-video-content-for-teacher-education

Cid-Cid, A. I., Guede-Cid, R., and Tolmos-Rodríguez-Piñero, P. (2018). Flipped classroom in preservice teacher training: An approach to a real mathematics classroom. [La classe renversée dans la formation initiale des enseignants: S'approcher à la réalité de la salle de classe de mathèmatiques; La clase invertida en la formación inicial del profesorado: Acercando la realidad del aula de matemáticas] Bordon, Revista De Pedagogia, 70(3), 77-93. doi: 10.13042/Bordon.2018.64127

Civitillo, S., Juang, L. P., Badra, M., and Schachner, M. K. (2019). The interplay between culturally responsive teaching, cultural diversity beliefs, and selfreflection: A multiple case study. Teaching and Teacher Education, 77, 341351. doi: $10.1016 /$ j.tate.2018.11.002

Coffey, A. M. (2014). Using video to develop skills in reflection in teacher education students. Australian Journal of Teacher Education, 39(9), 86-97. doi: 10.14221/ajte.2014v39n9.7

Creswell, J. W. (2007). Qualitative inquiry and research design: Choosing among five approaches. California, CA: Sage publications.

Creswell, J. W. (2011). Educational research: Planning, conducting, and evaluating quantitative. Upper Saddle River, NJ: Prentice Hall.

Çakır, R. ve Yıldırım, S. (2006). Bilgisayar öğretmenleri öğretmenlik mesleği için eğitiliyorlar mı? bir bilgisayar öğretmeni yetiştirme programının değerlendirilmesi. Ë̆itim ve Bilim, 31(142), 34-44. http://egitimvebilim.ted.org.tr/index.php/EB/article/view/840/194 adresinden erişilmiştir.

de Mesquita, P. B., Dean, R., and Young, B. (2010). Making sure what you see is what you get: Digital video technology and the pre-service preparation of teachers of elementary science. Contemporary Issues in Technology and Teacher Education, 10(3), 275-293. Retrieved from https://citejournal.s3.amazonaws.com/wp-content/uploads/2016/04/v10i3science1.pdf 
Deryakulu, D., and Olkun, S. (2007). Analysis of Computer Teachers' Online Discussion Forum Messages about Their Occupational Problems. Educational Technology \& Society, 10(4), 131-142. Retrieved from https://www.final.edu.tr/docs/02-analysis-of-computer-teachers-onlinediscussion-forum-messages-aboutpdf[1556872085].pdf

Doerr, H. M., and Thompson, T. (2004). Understanding teacher educators and their pre-service teachers through multi-media case studies of practice. Journal of Mathematics Teacher Education, 7(3), 175-201. doi: 10.1023/B:JMTE.0000033048.97096.39

Duman, D. (2012). Bilişim teknolojileri ögretmenlerinin özel alan yeterlikleri ve uygulanma düzeylerinin incelenmesi. (Yayımlanmamış yüksek lisans tezi) https://tez.yok.gov.tr/UlusalTezMerkezi/'nden edinilmiştir (Tez No. 321400).

Duffy, G. G., Miller, S., Parsons, S., and Meloth, M. (2009). Teachers as Metacognitive Professionals. In D. J. Hacker, J. Dunlosky, and A. C. Graesser (Eds.), Handbook of Metacognition in Education (pp. 240-256). Mahwah, NJ: Erlbaum.

Eilam, B., and Poyas, Y. (2006). Promoting awareness of the characteristics of classrooms' complexity: A course curriculum in teacher education. Teaching and Teacher Education, 22(3), 337-351. doi: 10.1016/j.tate.2005.11.004

Eilam, B., and Poyas, Y. (2009). Learning to teach: Enhancing pre-service teachers' awareness of the complexity of teaching-learning processes. Teachers and Teaching: Theory and Practice, 15(1), 87-107. doi: $10.1080 / 13540600802661337$

Ekiz, D. (2006). Kendini ve Başkalarını izleme: Sınıf Öğretmeni Adaylarının Yansitıc1 Günlükleri. İlköğretim Online, 5(1), 45-57. http://ilkogretimonline.org.tr/index.php/io/article/view/2002/1838 adresinden erişilmiştir.

Frost, J. H. (2010). Looking through the lens of a teacher's life: The power of prototypical stories in understanding teachers' instructional decisions in mathematics. Teaching and Teacher Education, 26(2), 225-233. doi:10.1016/j.tate.2009.03.020

Grant, T. J., and Kline, K. (2010). The impact of video-based lesson analysis on teachers thinking and practice. Teacher Development, 14(1), 69-83. doi: $10.1080 / 13664531003696600$

Hiebert, J., Morris, A. K., Berk, D., and Jansen, A. (2007). Preparing teachers to learn from teaching. Journal of Teacher Education, 58(1), 47-61. doi: $10.1177 / 0022487106295726$

Høynes, S., Klemp, T., and Nilssen, V. (2019). Mentoring prospective mathematics teachers as conductors of whole class dialogues - using video as a tool. Teaching and Teacher Education, 77, 287-298. doi:10.1016/j.tate.2018.10.014 
Jensen, R. A., Shepston, T. J., Connor, K., and Killmer, N. (1994, February). Fear of the known: using audio-visual technology as a tool for reflection in teacher education. Paper presented at the Annual Meeting of the Association of Teacher Education, Atlanta, GA.

Jiang, H., Ganoe, C., and Carroll, J. M. (2010). Four requirements for digital case study libraries. Education and Information Technologies, 15(3), 219-236. doi: 10.1007/s10639-009-9108-x

Johnson, D. C., and Matthews, W. K. (2017). Experienced general music teachers' instructional decision making. International Journal of Music Education, 35(2), 189-201. doi:10.1177/0255761415620531

Johnson, H. L., Dunlap, J. C., Verma, G., McClintock, E., DeBay, D. J., and Bourdeaux, B. (2019). Video-based teaching playgrounds: Designing online learning opportunities to foster professional noticing of teaching practices. TechTrends, 63(2), 160-169. doi: 10.1007/s11528-018-0286-5

Kennedy, M. M. (2019). How we learn about teacher learning. Review of Research in Education, 43(1), 138-162. doi: 10.3102/0091732X19838970

Keppens, K., Consuegra, E., Goossens, M., De Maeyer, S., and Vanderlinde, R. (2019). Measuring pre-service teachers' professional vision of inclusive classrooms: A video-based comparative judgement instrument. Teaching and Teacher Education, 78, 1-14. doi: 10.1016/j.tate.2018.10.007

Koç, M. (2011). Let's make a movie: Investigating pre-service teachers' reflections on using video-recorded role playing cases in turkey. Teaching and Teacher Education, 27(1), 95-106. doi:10.1016/j.tate.2010.07.006

Koç, Y., Peker, D., and Osmanoğlu, A. (2009). Supporting teacher professional development through online video case study discussions: An assemblage of preservice and inservice teachers and the case teacher. Teaching and Teacher Education, 25(8), 1158-1168. doi:10.1016/j.tate.2009.02.020

Koorland, M. A., Tuckman, B. T., Wallat, C., Long, B., Thomson, S., and Silverman, M. (1985). A pilot evaluation of the pre-ed program: An innovative studentteacher supervision model. Educational Technology, 25(10), 45-47. Retrieved from https://www.jstor.org/stable/44424495

Korthagen, F. A. J. (2010). Situated learning theory and the pedagogy of teacher education: Towards an integrative view of teacher behavior and teacher learning view of teacher behavior and teacher learning. Teaching and Teacher Education, 26, 98-106. doi: 10.1016/j.tate.2009.05.001

König, J., Blömeke, S., Klein, P., Suhl, U., Busse, A., and Kaiser, G. (2014). Is teachers' general pedagogical knowledge a premise for noticing and interpreting classroom situations? A video-based assessment approach. Teaching and Teacher Education, 38, 76-88. doi: 10.1016/j.tate.2013.11.004 
Kucan, L., Palincsar, A. S., Khasnabis, D., and Chang, C. I. (2009). The video viewing task: A source of information for assessing and addressing teacher understanding of text-based discussion. Teaching and Teacher Education, 25(3), 415-423. doi: 10.1016/j.tate.2008.09.003

Kurz, T. L., Llama, G., and Savenye, W. (2004). Issues and challenges of creating video cases to be used with preservice teachers. TechTrends, 49(4), 67-73. doi: $10.1007 / \mathrm{BF} 02824113$

Lee, G. C., and Wu, C. C. (2006). Enhancing the teaching experience of pre-service teachers through the use of videos in web-based computer-mediated communication (CMC). Innovations in Education and Teaching International, 43(4), 369-380. 10.1080/14703290600973836

Lincoln, Y. S., and Guba, E. G. (2013). The constructivist credo. California, CA: Left Coast Press.

Maclean, R., and White, S. (2007). Video reflection and the formation of teacher identity in a team of pre-service and experienced teachers. Reflective Practice, 8(1), 47-60. doi: 10.1080/14623940601138949

Merriam, S. B., (2009). Qualitative research: A guide to design and implementation. San Francisco, CA: John Wiley \& Sons.

Merseth, K. K. (1991, January). The case for cases in teacher education. AACTE Publications.

Merseth, K. K. (1994, November). Cases, case methods, and the professional development of educators. ERIC Digest.

Merseth, K. K. (1996). Cases and case methods in teacher education. Handbook of Research on Teacher Education, 2, 722-744. Retrieved from http://210.240.144.115/dyna/data/user/ndhu/files/201110141839070.pdf

Meschede, N., Fiebranz, A., Möller, K., and Steffensky, M. (2017). Teachers' professional vision, pedagogical content knowledge and beliefs: On its relation and differences between pre-service and in-service teachers. Teaching and Teacher Education, 66, 158-170. doi: 10.1016/j.tate.2017.04.010

Miller, M. J. (2009). Talking about our troubles: Using video-based dialogue to build preservice teachers' professional knowledge. The Teacher Educator, 44(3), 143163. doi: $10.1080 / 08878730902954167$

Miyata, H. (2002, December). A study of developing reflective practices for preservice teachers through a web-based electronic teaching portfolio and video-on demand assessment program. In Proceedings of the International Conference on Computers in Education, Washington, DC, pp. 1039-1043.

Moreno, R., and Ortegano-Layne, L. (2008). Do classroom exemplars promote the application of principles in teacher education? A comparison of videos, animations, and narratives. Educational Technology Research and Development, 56(4), 449-465. doi: 10.1007/s11423-006-9027-0 
Nielsen, B. L. (2015). Pre-service teachers' meaning-making when collaboratively analysing video from school practice for the bachelor project at college. European Journal of Teacher Education, 38(3), 341-357. doi: 10.1080/02619768.2014.983066

Olivero, F., John, P., and Sutherland, R. (2004). Seeing is believing: Using videopapers to transform teachers' professional knowledge and practice. Cambridge Journal of Education, 34(2), 179-191. doi: $10.1080 / 03057640410001700552$

Olkun, S., Altun, A., and Deryakulu, D. (2009). Development and evaluation of a case-based digital learning tool about children's mathematical thinking for elementary school teachers (L-TEST). European Journal of Teacher Education, 32(2), 151-165. doi: 10.1080/02619760902783875

Page, A., and Jones, M. (2018). Rethinking teacher education for classroom behaviour management: Investigation of an alternative model using an online professional experience in an Australian university. Australian Journal of Teacher Education, 43(11), 84-104. doi: 10.14221/ajte.2018v43n11.5

Patton, M. Q. (2014). Nitel araşttrma ve değerlendirme yöntemleri (M. Bütün ve S. B. Demir, Çev.). Ankara: Pegem Akademi.

Payne, J. W., Bettman, J. R., and Johnson, E. J. (1988). Adaptive strategy selection in decision making. Journal of Experimental Psychology: Learning, Memory, and Cognition, 14(3), $534 . \quad$ Retrieved from https://apps.dtic.mil/dtic/tr/fulltext/u2/a170858.pdf.

Perry, G., and Talley, S. (2001). Online video case studies and teacher education: A new tool for preservice education. Journal of Computing in Teacher Education, 17(4), 26-31. doi: 10.1080/10402454.2001.10784422

Rhine, S., and Bryant, J. (2007). Enhancing pre-service teachers' reflective practice with digital video-based dialogue. Reflective Practice, 8(3), 345-358. doi: $10.1080 / 14623940701424884$

Rich, P., and Hannafin, M. (2008). Capturing and assessing evidence of student teacher inquiry: A case study. Teaching and Teacher Education, 24(6), 14261440. doi: 10.1016/j.tate.2007.11.016

Rich, P. J., and Hannafin, M. (2009). Video annotation tools: Technologies to scaffold, structure, and transform teacher reflection. Journal of Teacher Education, 60(1), 52-67. doi: 10.1177/0022487108328486.

Rong, H., and Choi, I. (2019). Integrating failure in case-based learning: A conceptual framework for failure classification and its instructional implications. Educational Technology Research and Development, 67(3), 617-637. doi: $10.1007 / \mathrm{s} 11423-018-9629-3$ 
Roose, I., Goossens, M., Vanderlinde, R., Vantieghem, W., and Van Avermaet, P. (2018). Measuring professional vision of inclusive classrooms in secondary education through video-based comparative judgement: An expert study. Studies in Educational Evaluation, 56, 71-84. doi: 10.1016/j.stueduc.2017.11.007

Rosaen, C. L., Lundeberg, M., Cooper, M., Fritzen, A., and Terpstra, M. (2008). Noticing noticing: How does investigation of video records change how teachers reflect on their experiences? Journal of Teacher Education, 59(4), 347-360. doi: $10.1177 / 0022487108322128$

Rosaen, C. L., Lundeberg, M., Terpstra, M., Cooper, M., Fu, J., and Niu, R. (2009). Seeing through a different lens: What do interns learn when they make video cases of their own teaching? The Teacher Educator, 45(1), 1-22. doi: doi.org/10.1080/08878730903386849

Schieble, M., Vetter, A., and Meacham, M. (2015). A discourse analytic approach to video analysis of teaching: Aligning desired identities with practice. Journal of Teacher Education, 66(3), 245-260. doi: 10.1177/0022487115573264

Sharpe, L., Hu, C., Crawford, L., Gopinathan, S., Swe Khine, M., Ngoh Moo, S., and Wong, A. (2003). Enhancing multipoint desktop video conferencing (MDVC) with lesson video clips: Recent developments in pre-service teaching practice in Singapore. Teaching and Teacher Education, 19(5), 529-541. doi: 10.1016/S0742-051X(03)00050-7

Shen, P., Gromova, C. R., Zakirova, V. G., and Yalalov, F. G. (2017). Educational technology as a video cases in Teaching Psychology for Future Teachers. EURASIA Journal of Mathematics, Science and Technology education, 13(7), 3417-3429. doi: 10.12973/eurasia.2017.00736a

Sherin, M. G. (2007). The development of teachers' professional vision in video clubs. In R. Goldman, R. Pea, B. Barron, and S. Derry (Eds.), Video research in the learning sciences (pp. 383-395). Hillsdale, NJ: Erlbaum.

Sherin, M. G., and Van Es, E. A. (2005). Using video to support teachers' ability to notice classroom interactions. Journal of Technology and Teacher Education, 13(3), 475-491. Retrieved from https://www.learntechlib.org/primary/p/4824/.

Sherin, M. G., and Van Es, E. A. (2009). Effects of video club participation on teachers' professional vision. Journal of Teacher Education, 60(1), 20-37. doi: $10.1177 / 0022487108328155$

Shulman, L. (1992). Toward a pedagogy of cases. In J. Shulman (Ed.), Case methods in teacher education (pp. 1-29). New York: Teachers College Press.

Stockero, S. L. (2008). Using a video-based curriculum to develop a reflective stance in prospective mathematics teachers. Journal of Mathematics Teacher Education, 11(5), 373-394. doi: 10.1007/s10857-008-9079-7

Stockero, S. L., Rupnow, R. L., and Pascoe, A. E. (2017). Learning to notice important student mathematical thinking in complex classroom interactions. Teaching and Teacher Education, 63, 384-395. doi: 10.1016/j.tate.2017.01.006 
Sun, J., and van Es, E. A. (2015). An exploratory study of the influence that analyzing teaching has on preservice teachers' classroom practice. Journal of Teacher Education, 66(3), 201-214. doi: 10.1177/0022487115574103

Topuz, A. C. (2010). Bilgisayar öğretmenlerinin meslek hayatında karşılaştıkları sorunlara yönelik nitel bir araştırma. (Yayımlanmamış yüksek lisans tezi), https://tez.yok.gov.tr/UlusalTezMerkezi/'nden edinilmiştir (Tez No. 279884).

Van den Berg, E. (2001). An exploration of the use of multimedia cases as a reflective tool in teacher education. Research in Science Education, 31(2), 245-265. doi: 10.1023/A:1013193111324

Weber, K. E., Gold, B., Prilop, C. N., and Kleinknecht, M. (2018). Promoting preservice teachers' professional vision of classroom management during practical school training: Effects of a structured online- and video-based self-reflection and feedback intervention. Teaching and Teacher Education, 76, 39-49. doi: 10.1016/j.tate.2018.08.008

Wright, S. (1996). Case-Based Instruction: Linking Theory to Practice. Physical Educator, 53(4), 190-97. Retrieved from https://eric.ed.gov/?id=EJ541982

Xiao, B., and Tobin, J. (2018). The use of video as a tool for reflection with preservice teachers. Journal of Early Childhood Teacher Education, 39(4), 328-345. doi: 10.1080/10901027.2018.1516705

Yeh, H. (2018). Exploring the perceived benefits of the process of multimodal video making in developing multiliteracies. Language Learning and Technology, 22(2), 28-37. doi: 10125/44642

Yeh, C., and Santagata, R. (2015). Preservice teachers' learning to generate evidencebased hypotheses about the impact of mathematics teaching on learning. Journal of Teacher Education, 66(1), 21-34. doi: 10.1177/0022487114549470

Yerrick, R., Ross, D., and Molebash, P. (2005). Too close for comfort: Real-time science teaching reflections via digital video editing. Journal of Science Teacher Education, 16(4), 351-375. doi: 10.1007/s10972-005-1105-3

Yung, B. H. W., Wong, S. L., Cheng, M. W., Hui, C. S., and Hodson, D. (2007). Tracking pre-service teachers' changing conceptions of good science teaching: The role of progressive reflection with the same video. Research in Science Education, 37(3), 239-259. doi: 10.1007/s11165-006-9024-7

\section{Etik Kurul Kararı}

Bu araştırma Ankara Üniversitesi Etik Kurulu tarafindan 19.12.2016 tarihli, 27 toplantı ve 352 karar sayısı ile etik açıdan uygun bulunmuştur. 


\title{
A Method In Video Case-Based Instruction: Pre-Service Teachers' Own Video-Cases Edited And Discussed
}

\begin{tabular}{cccc}
\hline ARTICLE TYPE & Received Date & Accepted Date & Published Date \\
Research Article & 02.03 .2020 & 05.09 .2020 & 05.09 .2020 \\
\hline
\end{tabular}

\author{
Raziye Sancar (iD) 2 \\ Kirsehir Ahi Evran University \\ Deniz Deryakulu (iD) 3 \\ Ankara University
}

\begin{abstract}
This study aimed to examine the video case-based instruction process, which includes the faceto-face discussion of video-cases edited by pre-service teachers with their own in-class teaching experiences. For these purposes, the research was conducted as a case study by adopting a qualitative research approach. The research group consists of 16 ( 9 female, 7 male) pre-service teachers who took the course of Teaching Practice for the first time in the Department of CEIT, Faculty of Educational Sciences, Ankara University in 2016-2017 academic year. The research process includes the recording of in-class teaching experiences of pre-service teachers, preparing these teaching experiences as video-cases edited by the pre-service teachers, monitoring, and discussing the video-cases. The data of the study was obtained from the process evaluation interviews with the prospective teachers using a semi-structured interview form. As a result of this research, in the video case-based instruction process, it was determined that the pre-service teachers had the opportunity to monitor themselves, that they noticed the change in both themselves and their friends, that they learn to accept criticism. Also, it was determined that their appreciation by their peers and caring about their thoughts were valuable and important. Finally, it was found that the video-based instruction process was beneficial for preservice teachers in order to gain experience (more than they could gain), discuss and develop critical skills, as well as to obtain feedback that could not be obtained from school counselors.
\end{abstract}

Keywords: Video-case, video case-based instruction, video editing, video discussing, teacher education.

\footnotetext{
${ }^{1}$ This study was produced from a doctoral dissertation titled "A Qualitative Research on Using StudentTeachers' Own Video-Cases to Analyze Their Instructional Decisions” by Raziye Sancar.

${ }^{2}$ Sorumlu Yazar: Ph.D., Kursehir Ahi Evran University, Faculty of Education, Department of CITE, E-mail: raziyesancar@gmail.com, https://orcid.org/0000-0002-2875-9233

${ }^{3}$ Professor, Ankara University, Faculty of Educational Science, Department of CITE, E-mail: deryakulu@ankara.edu.tr, , https://orcid.org/0000-0002-6974-7183
} 


\section{Purpose and Significance}

A case includes a problem, the process of problem-solving, as well as the results of problem-solving; It is defined as a narrative or story representing the complete set of events related to an event (Rong and Choi, 2019). Case-based instruction is the teaching method in which cases are used with various content, environment, and design features; With the case-based instruction method, a communication channel is created between advisor and pre-service teacher. Additionally, pre-service teachers can be provided with more field experiences, and cases can also be used as an assessment tool in the teaching process (Merseth, 1994). Situational skills, as an essential mediator among professional knowledge, beliefs, and teaching experiences in teacher education, are getting more and more attention today (Meschede et al., 2017). Video-case-based instruction is seen as an essential method in the transfer of context-specific skills; video-cases allow pre-service teachers to access different contexts and situations, as well as to benefit from the application experiences of others (Olkun et al., 2009). With the video-case-based instruction method, it is possible to develop pre-service teachers' awareness of in-class teaching experiences (Brunvand, 2010; Johnson et al. 2019; Page and Jones, 2018; Stockero et al., 2017). In addition, it is seen as a very important step for teacher education to give pre-service teachers the opportunity to discuss their own in-class experiences regularly with peers and advisers in the case-based instruction method (Moore, 1998). In the research, the preservice teachers' own experiences are based on the benefits such as providing more experience opportunities, providing regular feedback, transferring of theoretical knowledge into practice. Also, video-case-based instructions used for pre-service teachers' own experiences enable the transfer of context-specific skills that are not easy to achieve by applying for teacher training programs in our country. It is aimed to evaluate the video-case-based instruction process designed in the form of the preservice teachers editing their own in-class teaching experiences and discussing with peers.

\section{Method}

This study aims to examine the video-case-based instruction process, which was developed by recording the first teaching experiences of pre-service teachers in digital video, developed by themselves, and discussing them with their peers. It is structured as a case study by adopting a qualitative research approach. Case study, definition, and analysis of a system with defined limits; it is defined as an event, program, process, and even a strategy to question one or more individuals (Merriam, 2009). While the situation can be a single person, multiple individuals (together or individually), a program, an event, it can also represent a process that includes several stages of a series of activities (Creswell, 2011). What is defined as the situation in this research is the research process itself; the situation is a process in which more than one activity takes place, and various stages are designed together. Starting with the recording of pre-service teachers' teaching experiences; the teaching process, which includes the editing of these video recordings by the pre-service teachers and the 
discussion of the edited video-cases in the discussion sessions, was examined as a situation. Each stage was repeated for all teacher candidates for three separate teaching experiences. In other words, three different in-class teaching experiences of pre-service teachers (after completion of the implementation cycle in the process) were recorded, constructed by them, and discussed with their peers. Each of the preservice teachers in the study group developed three edited video-cases at the end of the process; they had the opportunity to watch and discuss 48 different classroom teaching experiences in total, 16 at each stage. In the research, the interview was used as the primary data source. The participants were interviewed after the video-casebased instruction process. A semi-structured interview form was prepared by reading the relevant literature before the interview. Before the interview form was finalized, four experts from the field were consulted. Necessary arrangements were made in the interview form according to the feedback of the field experts. As suggested by Lincoln and Guba (2013) in the research, each stage of the process, such as the design of the process, the preparation of interview questions, the analysis and interpretation of the data, was supervised by field experts so that in this research was ensured confirmability audit. The experts' feedback on the research findings has increased the transferability of the research. Besides, during the reporting of the research, direct citations and detailed descriptions were used to ensure transferability and consistency in the research.

\section{Results}

The pre-service teachers mentioned the benefits of viewing their in-class teaching experiences, such as an experience that every teacher and prospective teacher should have, a different and joyful experience. They also state that viewing in-class teaching experiences enables them to increase awareness of those in the classroom, evaluate their experiences, and learn from experiences. Pre-service teachers stated that sharing experience, criticizing, thinking/focusing on experience, fitting into time (editing their video-cases) on the issues related to editing their own in-class teaching experiences. Pre-service teachers explain their experiences evaluated by their peers over the negative situations that usually occur in the experience. Almost all of the preservice teachers emphasized allowing their peers to monitor, evaluate, and see their deficiencies in their experiences. In the video-case based instruction process, preservice teachers watched the video-cases edited from their peers' classroom teaching experiences during the discussion sessions and gave them feedback about these experiences. In this process, considering the intensity of the discussion sessions, the person who edited the video-case was first given the right to make an explanation, and then the group discussions were started. Regarding the video-cases prepared with peers' in-class teaching experiences, pre-service teachers emphasize role-modeling, accumulating experience, focusing on improvements/changes. Pre-service teachers generally focused on feedback regarding the discussions. Moreover, they addressed issues related to the content of feedback and criticism, the nature of feedback and criticism, and the development of feedback and criticism on discussion sessions. 
It is seen that the most important reason for pre-service teachers to participate in this study is to think to be useful for them and to wonder about the process. Regarding the content of the seminar organized at the beginning of the research process, preservice teachers had different views about the adequacy of the explanations, while the majority of them found the explanations sufficient. However, they noted that there are some points that need to be improved during the implementation phase. The discussion sessions took more time than expected at the beginning of the process, so it is seen requiring much dedication for pre-service teachers is their participation in discussion sessions. Prospective teachers also expressed this situation during process evaluation interviews. Regarding the pre-service teachers' positive emotions in the process, it is seen that they have mentioned, such as being able to follow themselves, noticing the change in both themselves and peers, learning to accept criticism, being appreciated by their peers and consideration of their ideas. Besides, pre-service teachers emphasized that the video-case based instruction process is effective, efficient, and attractive. Finally, all pre-service teachers stated that they might want to participate in a study with similar processes and expectations.

\section{Discussion and Conclusions}

In the video-case-based teaching process, as stated in the references of the preservice teachers participated in the process, enables them to get useful feedback, to see themselves, students' behavior and unnoticed situations during their experience. Also, the process provides to generate ideas about what pre-service teachers can do when they face similar situations. In the teaching process, experience plays an important role, so video-case based instruction method allows pre-service teachers to acquire the experiences of others, which includes more cities, schools, classrooms, and students than they can only experience at School Experience and Teaching Practice courses. In addition, pre-service teachers can be provided to develop "routines/habits" through these experiences. In the video-case based instruction process carried out in this research, pre-service teachers play a role as active participants, and their in-class experiences are at the center of the instructions. Preservices teachers underlined being able to analyze themselves, to notice the change both in themselves and in their friends, to develop criticism, to be liked by their peers, and to consider their opinions. Besides, the pre-service teachers emphasized that the video-case based instruction process gives them the ability to communicate effectively as a teacher, the ability to communicate and interact with their students, and awareness of the in-class teaching process and procedure. All pre-service teachers expressed positive opinions about continuing the process and participating in similar processes. Based on these positive evaluations, it can be said that video-case based instruction is a source of motivation for pre-service teachers. Similar practices can be used for different disciplines in teacher education. Based on the benefits obtained through the use of video-cases in teacher education; There is a need for large-scale process designs and research initiatives where teacher-candidates can use video-cases and support their continuous professional development, not only during their education but also throughout their professional life. 


\section{The Ethical Committee Approval}

This research has been found ethically appropriate by Ankara University Ethics Committee with 27 meeting and 352 decision numbers dated 12.19.2016. 